\title{
EXPERIMENTAL STUDIES ON NOISE SUSCEPTIBILITY \\ IN IMPAIRMENT OF CIRCULATION REGULATING FUNCTION
}

\author{
By \\ Shigeo SUGIYAMA \\ From the Department of Oto-Rhino-Laryngology, Osaka University \\ Medical School (Director: Prof. T. Hasegawa)
}

1) Following excision of the carotid sinus nerves of the rabbit blood pressure increased by an average of $29 \mathrm{mmHg}$, and vasoconstriction of the stria vascularis was histopathologically observed, without any destructive changes.

2) Unilaterl or bilateral removal of the superior cervical ganglion was followed by the vasodilatation of the stria vascularis, appearance of nubecula in the endo- and perilymph and swelling of the cells in some organs of Corti.

3) In the control animals acoustic stimulation by a 110 phon white noise for one hour daily for 10 successive days caused no cochlear lesion, while in the treated animals it resulted in the destruction of the hair-cells and other structures of the organ of Corti and the stria vascularis. This acoustic trauma was produced bilaterally in the case of unilateral excision as well, and was marked at the second turn.

4) The reduced C.M. potentials of normal rabbits on exposure to a 110 phon white noise for 30 minutes was restored to normal in 15 to 20 minutes, but in the case of bilateral gangliectomy only a small amount of recovery was observed. The unilaterally gangliectomized animals similarly showed poor recovery on the affected side, with nearly the same recovery on the opposite side as the normal subjects.

5) These results apparently indicate that increased noise susceptibility is caused by the surgical removal of the carotid sinus nerve or superior cervical ganglion.

\section{循環調節障害が音響受傷性に及ぼす 影響の実験的研 究}

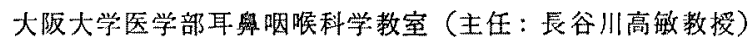 \\ 医学士杉山茂少
}

目次

I 緒言

1 病理組的学的研究

第 1 章 実験動物亚びに实験方法

第 1 節 実驗 動物

第 2 節 音響负荷装置

第 3 節 負荷条件

第 4 節手術方法

第 1 项 交感神経上䫫神経節剔出術
第 2 項頙勤脈洞神経剔出術

第 5 節 血压測定法

第 6 節 固定並びに染色

第 2 章 実験成絃

第 1 節 正常動物音響負荷群

第 1 項 一般 所見

第 2 項病理組的学的見

第3 項 小括

第 2 節 偱環調節障害動物音響非負荷碓 


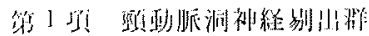

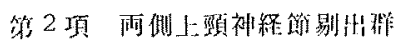

第 3 项 一侧上㥧被経節剔出辚

第4 項 小括

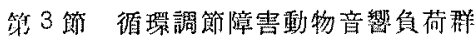

第 1 項 頸動眽洞神経剔出羣

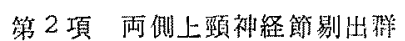

第 3 項 一側上頸神経節剔州班

第4項 小 括

III 電気生理学的砳究

第 1 章 实験動物这びに笑験方法

第 1 節 実虽動物

第2 節 实験装圈

第 3 節 C.M. 誘導法

筙 4 節 負荷条件及び観察方法

第 5 節 然麻醉唀導法について

第 2 章 実験成緥

第 1 節 正常 群

第 2 節 両側上頸神经節剔出群

第 3 節 一側上頸神経節剔出群

第 4 節 小 括

IV 総括並びに考按

$V$ 結語

\section{I 緒 言}

音響外傷に関寸る研究は St. v. Stein, Wittmaack 20), 吉井21)等を端緒として多くの研究者が健事し幾多 の耀やかしい臬續を举げてきた，当初は音知賞現象の解 明を目的として始められたが，戦後は著しい交通機関の 発達, 工業地带の抬㖘さらにジェット兵器の登場等から

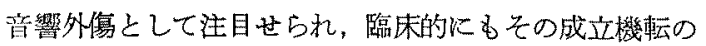
追求, 治寮さらには予防へと進んできた，今日では工場 騷音等の特殊な眔境は云らに及ばず，大都市の虽音問題 む深く取り上げねばならぬ段階に至つている。

今日の社会生活は日常に扣ける騒音疲学, 交通戦争及 び複雑な社会機構等を包含して，異常なストレス環境と も云うべき霞の中で営まれていると云克よら。これは心 身のストレスが大きな原因たと考克られるメニエル氏病 が，戦後急激に增加している事でもらかがい知る事がで きる41)。この所掼ストレスと最る深い関係にあるのは自 律神経系で，ストレスの增加はその不安定状態を起しさ らに血液循稲の変調をもさたす また逆に考えるとこの よらな状態はストレスを受け易い集備状態となる事も想 像されよら。しかしながら音響外稘に関する従来の磍

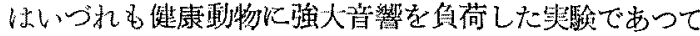
このようなストレス準惜状態に扔ける個体の音響受傷性 がいかたなるかについての研究は充分行われていない。 長谷川教授はことに音響外傷に抢ける個体の潜在性要素 を重視され，実験的にも佐藤 ${ }^{37)}$ ，松原 ${ }^{49)}$, 菊池 ${ }^{82)}$,山川 ${ }^{50)}$ 等一連の研究により，個体汇潜在性病变が存在する時は 音響受傷性が亢進する事を明らかにされた。このような 内因的要素の一つとして循環調節障害も重視せねばなら ない．何故なら内耳は高度に分化した神経系と多数の毛 細血管を有し，しかる終未動脈といら特徵を持つ感営器 で，その機能や疾患汇言及する場合に内耳血管を切り晟 して考学る事ができないからである，両者の関係偟つい ては古くから注目されて机り Politzer (1908) は㠰発的 に睹最、耳鳴、難聴をきたす疾患を Angioneurotische Akustikuslähmung と呼び, Kobrack 18) (1922) は自 律神経の unbalance から内耳住血あるいは算血の拉 きる疾患を Angioneurotische Oktavuskrise と名つ け, Fowler ${ }^{8)}$ (1950) は究発性難聴の原因を内耳血行障 害に求めている. 長谷川教授は内耳病变之血液循環系之 の関係を強調され，重曹注射による末梢循環の改善によ

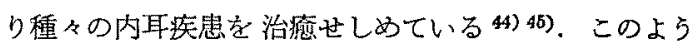
に内耳疾患之血流状態之は密接な関係尔るため，循環 調節の障害が存在する場合騷音に対する音響受傷性にい か比影響するかを追求する事は興味深い事である。この よらな観点から著者は家种の頸動脈洞神経あるいは交感 神経上頸神経節を剔出し実験的儿循環調節障害を起さし め,この際の音響受賃性の状態を知らんとして本研究を 試みた。

\section{II 病理組織学的研究}

形態学的な䂰究方法は基本的なもので全ての研究に重 きをなしている事はは言をまたない，従つて内耳諸組織を 検索するに当つてる病理組織学的な力法が基本となる. しかも生体固定法の創案以来，内耳の微細構造炎観察し

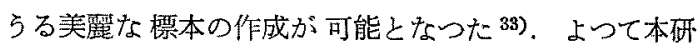
究を行うに際して聴器の障害の程度を病理組䄉学的に検 討した。. 検索に際しては内耳の特殊性に鑑み，高度な感 覚神経を有するコルチ器及び豊富な毛細血管を有する血 管条に特に注目乙，へマトキシリン・エオシン重染色に よつて前者の変化を，墨汁染色にて後者の状態を追求し た.

\section{第1章 実験動物及び実験方法}

第 1 節 奏験 動物

体重 $2.0 \sim 2.5 \mathrm{~kg}$ の健康な白色成熟家鬼を使用した。 
耳鏡検査で耳坮栓塞, 慢性中耳炎に特汇注意し鼓膜が正 常で回転後腿振に異常のないのを確かめてから笑験に供 した，又環境に慣れさせるため所定の飼育箱で1週間飼 育してから実験を行つた。

第 2 節 音響角荷䒾置

実験室には阪大耳泉科教室の防音室を使用した。負荷 音響にはヨシノックス 51-Dオジオメーターより発振す る白色雑音（以下 W.N. と略与）を用ひ，山水 Q-3535 增幅器を通じ，実験室の一隅に固定されたビタタ一留レ フレックス・ホーンスピーカーに薄いた．実験動物は固 定筒に入れスビーカーの前面約 $1 \mathrm{~m}$ の所に固定した。

第3節 真荷条件

負荷条件としては W.N. 100 フォン・1時間/日・連 続 5 日，同連繶 10 日，110 フォン・1時間/日・遳続 5 日，同連続 10 日，110フォン・2 時間/日・連続 5 日, 120 フオン・1 時間/日・連続10日の6檗を採用した。 その W.N. の周波数特性は第1 図の如くである. 刺㦸 音響としては純音を用いる实験が多いが W.N. を用い たのは，实生活に純音と云ら刺㦸挝检めて特殊な環境を 除いてはなく，䧴音・騒音の類であり，オージオメータ 一から発振する W.N. と社会生活に見られる騒音とは 勿論同一視小できないが，少しでも近似せる刺㦸にせん がため及び定常波が起りにくく各個休閒の誤差を少くし 得るためである. 又後述の交感神絽:上頸神経節あるいは 頸動脈洞神経の剔出を行つた場合は，手術後2 日目又は 1 過間目より騒音負荷を開始した，負荷音は常に一定の

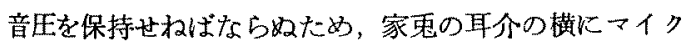
ロフォンを置き，側室にてりオンの指示騒音計 N 1103 を用いて测定した。

第 1 図 白色雑音周波数特性

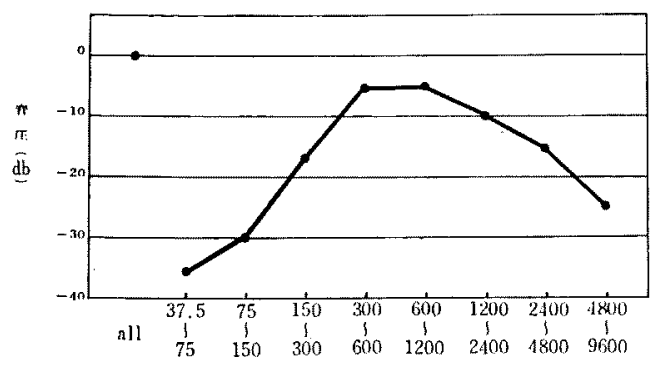

周波数带 $(\mathrm{cps})$

第4節手術方法

第 1 項 交感神経:上頸神経節剔出術

家鬼を固定台上に昘位に特に前頸部を伸展せしめるょ
らに緊縛し，钼部の毛を刈りマージニンで十分消毒した。 切開は正中線よりやや側方で下顎角の内面やや頭側より 下方に，約 $5 \mathrm{~cm}$ の長さに伸ばした．表層の筋膜を開き，

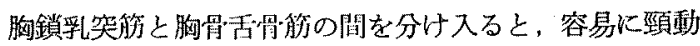

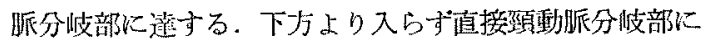
入つたのは，周四の血管神経特に迷走神経の提穓を避け

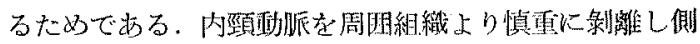
方に率引すれば，これと交叉寸る上らに存在する交感神 経:上頸神絽節を見出すことができる。 そこで上頸神経節 を周囲より䟝睢し吻合を切り，節端上下 $5 \mathrm{~mm}$ の所で切 断剔出した.

第 2 項 頸動脈洞神経剔出術

上頸神経節剔出術と同操作で分岐部に至り内项動脈を 周团組織上り注意深く剝離する. その際喉頭動脈は必ず

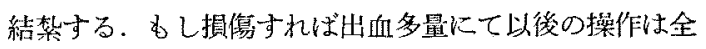
く不可能となる.頸動脈洞には頸動脈球が存在するが， 実際には周囲の脂肪及び結合組織と区別し難い，従つて これら脂肪及び結合組織を除去し内頸動脈壁の神経對を 剥礁するのであるが，頚動脈洞の血管壁は極めて菲薄で しかも神経は細く血管壁自体の如き感があるため，手術

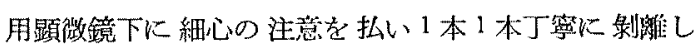
た．この操作は困難で時には血管破壦による大出血をき たし死亡する事る再三であつた，また洞神経の剔出は雨 側同時に行和らとしたが，一侧剔出後でも腹吸促迫し渐 時食欲不振となるために，他側の手術は必ず 1 週間の間 隔を膡いて一般状態の回復するのを待つて施行した，手 術が両側ともいが上手に手早くできた場合でも，食欲 不振は著明で体重減少著しく死亡する事もあつた。

第 5 節 血圧測定法

文献によれば両側の頸動脈洞神䌊を剔出する時，持続 的高血圧を招来すると云われている 13) 31)。従つて頸䡃 脈洞神経を剔出するに当り，合せて血圧の変動を測定し た. 实驗的血圧測定法には非観血的及び钼血的方法があ るが，前者は専ら耳翼中心政脈測定法を採用するるので あり，每日測定し経過を追い得る利点はあるが，变䡃が 極めて湤しいため安定した血圧值を得にくいので行わな からた，後者は普通頸動脈にカニニーレを挿入し测定す るのであるが, 同一家鬼て頸動脈洞神経剔出前後の血王 差を得るために股動脈で測定した，特に術後血王は 2 回 目の洞神経剔出を行つてから】週間後に測定した。

测定時恃家患を等位に固定し、ミンダール（ペントパ ルビタール Na） $1.5 \mathrm{cc} / \mathrm{kg}$ の静注で麻酭し, 血圧の安定 するのを待つて 5 分稫に 4 回計测しその可均値を以って 
その家束の血圧としたなお，血王測定後は両側の股動 眽とる結紫する事になるが，副行枝の発達するためか下 肢の運動には特に翼常を認めなかつた。

第6 節 固定並びに染色

怔物は全て或駩終了後 2 日目に生体国定を行つた。家 鬼の体温に近く加温した生理的食熄水をるつて血管洗深 後山川法によりWittmaack 氏液で生体固定した．固定 液注入後住手早く解剖し，中耳骨胞をつけた立側頍骨 を取り出して 1 週閆同液で固定した．脱灰は $5 \%$ の硝酸 ホルマリンを用い每日交換して 5〜7日で完了した，次 いで順次 70, 80, 90, 95, 99, 100\%のアルコール及び無 水エーテルアルコールで脱水した ツェロイジン包埋は 順次 $2 \%, 4 \%, 8 \%$ に濃度を上げ，乾懆後固つた標本か $515 \mu$ の水平連続切片を作製へマトキシリン・エオシ ン重染色を施した。

内耳血管条の变化を知るために一部は墨汁染色を行つ た. 液は墨汁 15, ゼラチン7, 水 100 の嘒合で温めて注 入し，ゼラチンを固めるため冷却してから前記重染色と 同操作を継続した：この塨合切片は $100 \mu$ で妃り，周困 の輸廓を出すために極めて薄くへマトキシリンのみで染 色した.

\section{第 2 章 实験成繥}

第 1 節 正常動物音響負荷群

第 1 項 一般所見

各群とも実駼期間中は食欲不振や下疬をきたすことも なく，健康な状態を持続することがでさた，実騟䅂了後 耳鏡検查で特に鼓膜に穿孔をさたしているすのは無かつ た.

第 2 項 病理組織学的所見

i) 第1 群 100 フォン・1 時間/日・逨続 5 日 (No. 3, No. 4)

ii) 第 2 群 100 フォン・1 洔間/日・連続 10 日 (No. 1, No. 2)

iii) 第 3 群 110 フォン・1 時間/日・連続 5 日 (No. 7, No. 8)

iv）第 4 群 110 フォン・1 時閪/日・連続10日 (No. 5, No. 6)

v) 第 5 群 110 フォン・2 時間/日・連続 5 日 (No. 22, No. 23, No. 24)

以上 5 群の所見は全体を通じて全く正常であつた，即 ち外耳，中耳に認抑き病変はなく，蟜牛迷路において は内外リンパ腔は一般に清登であり,コルチ器は全回忶 に亘りなん等変化を認めなかつた．即ち内外有毛細胞は
正常であり支持細胞にも変性所見は見られず，各細胞䗷 界は明膫であつた。堅道内緎維も多くの場合明瞭に見ら れた、唯，一部の例では外リンパ腔に極めてわずかの小 出血が見られた (No. 5, No.22).

基碟膜下組胞群は正常の配列を示し，基喽膜，コルチ 獏，ラ氏膜す正常に伸展していた。

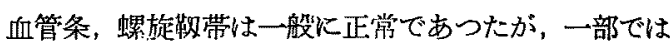
第 2 回転で著明に拨張する血管が見られた（No. 22）. 螺旋神経節紐胞は全回転に亘り变化は見られなかつた.

vi）第6群 120 フォン・1時間/日・連続10日

$$
\text { (No. 32, No. 35) }
$$

コルチ器は全回転に亘り強い:音響障書の像を示し, 内 外有毛細胞の消失が見られた．变化は支持細胞にも及び 各支持細胞山溷㯰変性して細胞境界怡えど認め難い、 第1 回転では有毛細胞のみならずダイテルス・ヘンゼン

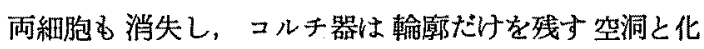
乙，外方ではクラウジイウス細胞の一部が扁平な細胞塊 として残存するのみであつた，最子変化の甚しいのは第 2 回転で両側ともコルチ器の全久損が見られた。

基礎膜下細胞群もその配列が乱れ著明な数の減少をき たした、その程度はコルチ器の障害の度合にほぼ比例 し，第 2 回転初部では殆んと消失するに至つだ。

基礎膜，ラ氏膜は正常に伸展し屈典，離断を諗めるる のは㫮からた.コルチ膜は軽度の膨化の認められるすの もあるが，概して正常の形態を保つけれどる，コルチ器 の全欠損のあつた第 2 回転初部では，尖端が䋐維状に㒕 開する像が見られた。

血管条，螺旋菻带は正常であり，第 2 回転で螺旋都 帯より血管条に移入する血管像の見られた例ああつた (No. 35).

内外リンパ腔は清澄であるが，第 2 回転初部の内リ ンパ空外下隅に 極めて 軽度の小出血を見る 例があつた (No. 35). 螺旋神絽節細胞は全く正競であつた。

第3 項 小 括

第 1 群ないし第 5 群では外耳, 中耳に病的变化を認め ず，蝸牛迷路に扣いても外りンパ腔の一部に極めて軽度 の小出血及び血管条の血管搪㖘を見る以外，㱠んど病的 変化はなく，内外有毛細胞始め支持細胞，血管条，蝶旋 勒带，内外リンパ腔，蟔旋神経節等は全回転に亘り正常 であつた，特火有毛細胞の変性像は全く認められない、非 を全回転に亘つて確かめ得たのである．第 4 群と第 5 群 を比校子れば，音智障書の認められない檕に変りはない が，後者では小出血を見たり血管条に血管の脑張をきた 
して招り，両者は同じ刺㦸量ながら後者では短期間に受 けていることを考慮すれば，動物にはそれだけ血管系の 負担になつていると考光られた，

これ等に反して第 6 群では著明な音響障害の所見が見 られ，有毛細胞は云うに及ばずコルチ器の他の部分にま で変化が及び， ニルチ器の全欠損さ光見られたのであ

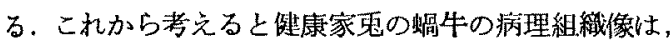
1 日1 時間連続10日の W.N. を受けた場合，110フオ ンと 120 フオンで非常に違つてくる. 即ち 110 フオンの 負荷なら正常で 120 フオンを負荷すると著明な变化があ り，障害を受けるか否かの一線は110〜120 フォンの間 に劃せられると云ら事である.

第 2 節 循環調節障害動物音響非負荷群

第 1 項 頸動脈洞神経剔出群

i) 一般所見

剔出直後は呼吸促准し楀汗分泌多く，以後数日間は食
欲不振で動作緩慢となり，一般に元気を要失せる態であ

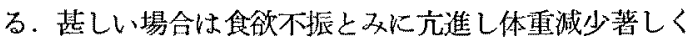
死に至る事も再三であつた，従つて血圧測定のための手 術を併せて前後 4 回の手術に耐光て生体固定されたるの は約了分の1に過きなからたが，これらの動物でも多少 とも体重の減少让る場合が多かつた，代表例の経過を示 すと第1表の如くである。

ii) 血玨について

血圧测定法の項で述べた如く5 分間隔で 4 度測定した が，第 2 図に示怙如く非常に安定して括り特に秒摇の著 しい例は無かつた。 4 回の計測值を夫及算術平均した值 をその家象の術前術後の血压とした．絬果恃第 3 図に示 す如くである. 正常血压は垠も低いもので $80 \mathrm{mmHg}$ ， 最も高いもので $111 \mathrm{mmHg}$ で $100 \mathrm{mmHg}$ 前後の值を 示すむのが多く，5例の幵均は $98 \mathrm{mmHg}$ であつた．国 府 35)に上机ば頸動脈で計つた家鬼の正常血王は 90〜

第 1 表 洞神経剔出家鬼の経過

\begin{tabular}{|c|c|c|c|c|c|c|c|c|c|}
\hline $\begin{array}{l}\text { 家 } \\
\text { 番 }\end{array}$ & $\begin{array}{l}\text { 乘 } \\
\text { 㞻 }\end{array}$ & 雌崔 & 術前体重 & $\begin{array}{l}\text { 第 一回 } \\
\text { 血 正湘定 }\end{array}$ & $\begin{array}{l}\text { 左 洞 } \\
\text { 神経剔出 }\end{array}$ & $\begin{array}{l}\text { 右洞 } \\
\text { 柛程剔出 }\end{array}$ & 術後体央 & 符三回 & 固 \\
\hline No. & 72 & q & $\begin{array}{l}20 / \| \\
2,0 \mathrm{~kg}\end{array}$ & $\begin{array}{r}22 / \| \\
100 \mathrm{mmHg}\end{array}$ & $26 / \|$ & $6 / 111$ & $\begin{array}{l}14 / \mathrm{II} \\
1,6 \mathrm{~kg}\end{array}$ & $\begin{array}{r}23 / \text { II } \\
136 \mathrm{mmHg}\end{array}$ & $23 / 11$ \\
\hline No. & 73 & $\hat{0}$ & $\begin{array}{l}20 / \mathrm{il} \\
2.5 \mathrm{~kg}\end{array}$ & $\begin{array}{r}22 / \| \\
111 \mathrm{mmHg}\end{array}$ & $26 / 11$ & $6 / 111$ & $\begin{array}{l}14 / \mathbb{I I} \\
1.6 \mathrm{~kg}\end{array}$ & $\begin{array}{r}14 / \mathrm{ll} \\
124 \mathrm{mmHg}\end{array}$ & $23 /$ III \\
\hline
\end{tabular}

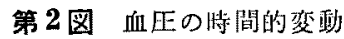

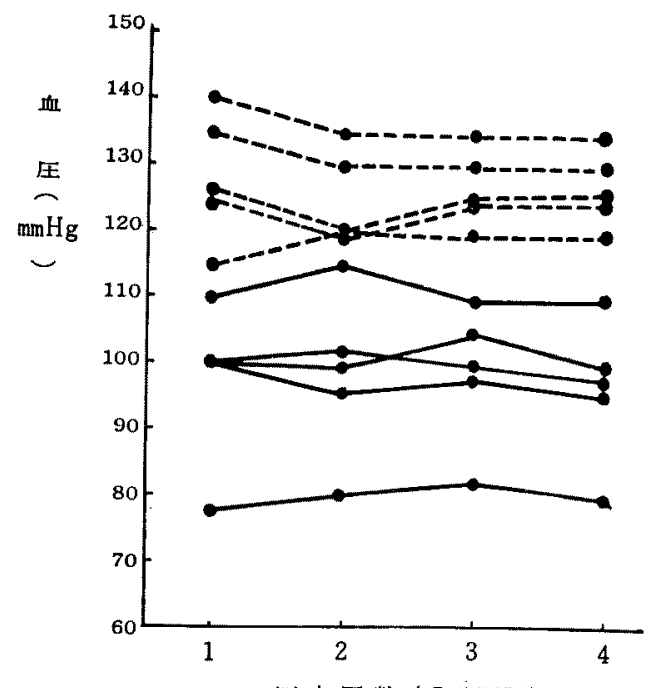

测定回数 ( 5 分間隔)

奏線：術前血压点积：術後血正

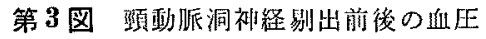

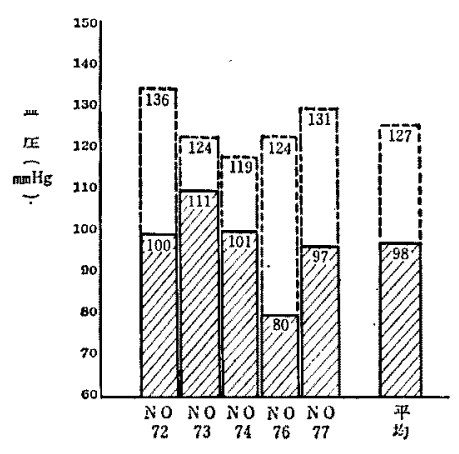

奏線：衔前点楾：琎後

$120 \mathrm{mmHg}$ で，股動脈ではそれより約 $10 \mathrm{mmHg}$ 前後 低い値を示寸と云われているが，著者の計測値もこの範 围に入るるのであつた。

洞神経剔出後の血厈は 1 週間目から17日日までの間 に测定したが，全例とも血压上笔をきたして括り，繁変 
化であつたり下降したりする例はなかった。最も顕著な 場合は笑に $44 \mathrm{mmHg}$ の上昇をきたし (No.76)，最む 少いものでも $13 \mathrm{mmHg}$ で (No. 73), 5 例を平均すると $29 \mathrm{mmHg}$ の血压上昇を来した索になる。

iii) 病理組織兴的所見

全回転に亘り病的変化は認められない。つ本りコルチ 器は有毛細胞はじめ各支持細胞は上くその形態を保ち，

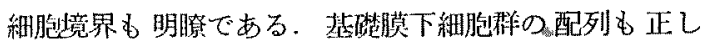
く，基礎膜，ラ氏膜，コルチ膜は正常に伸展している. 血管条, 螺施虭带に病的な变化はないが血管はやや収縮 気味である.内外リンハ腔は清澄で，螺旋神経節組胞も 全く正常である (No.66, No.67, No. 72).

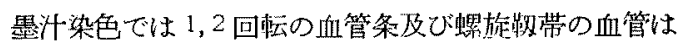

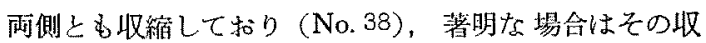
緶が全回枟に亘り，血管条に恃点在する墨汁が見られる のみで，血管の走行は全く追う事ができなかった（No. 73).

第 2 項 雨揑上頸神絟節剔出群

i) 一般所見

剔出は雨側同時に行つたが，直後上り著明な縮曈が見 られ約斗数には球結膜の充血索きたした，充血は数日に して回復したが，縮噇は殆しど生体固定時まで続いた。 軽度の下痱や食欲不振の他特以認むべき变化は無かつ た．满足すべき手術であり後出血も無かつたにも抱ら

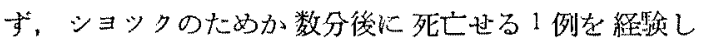
た。

ii) 病理組織学的所見

1）剔出後 2 日目固定群

コルチ器の各細胞は膨化の傾向を示し，胞体恃明るく 核も淡染し透明度を增している。第2 回転に著明である

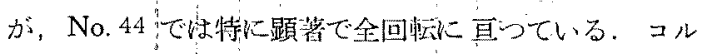
チ膜及びラ氏膜も膨化淡染し愿さ至增している埸合が多

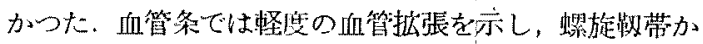
ら执張せる伹管の移入せる像も見られた (No. 44)。内 外リンパ腔は No. 41 では清澄であるが, No. 44 では左 右とも随所以へマトキシ》ンに淡染する均質な雲絮状物 質を見る。内リン・腔の力が著明で右側第1 回枟終部か ら第 2 回枟初部にかけて外側に寄つて存在し, 左側では 第 2 回忶初部上り第 3 回枟にかけてかなり多量存在し， 符 2 回枟ではラ氏膜に沿つて蛙り下方ではコルテ膜を包 みラ氏膜に癒着せしめている。外リンパ腔では右側第 2 回転初部の上外隅にごくかずかに存在したに過ぎなかっ た. 螺旋神経節には特に変化を認めなかつた。
口）剔出後 2 週間目固定群

コルチ器自体には全回転に亘り著变を認めないか，第 2 回転では有毛細胞はじめ 各細胞は軽度の膨張像を示 す. 内リンバ腔では全回転に亘り上外隅及び内外螺旋溝 に㳂つて附着する㥛めてわずかの雲架状物質を見る。特 に内螦旋滗週辺のものは第 2 回転でコルチ膜の尖端を包 みラ氏膜に癋着せしめている。外リンベ腔は清登であ る. 基濋膜，基濋膜下細胞群，血管条，螺旋靬带，蛽旋 神経節細胞等に恔変化を見なかつた (No. 69).

八) 畦汁染色群

正常家束の墨汁染色所見に比し，1・2 回転で血管条 の血管け甚だ著明に抬張している (N. 43, No. 62, No.

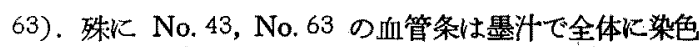

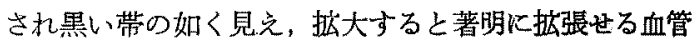
は第 1 回転では樹校状を, 第 2 回枟では太く短い棍棒状 を呈した。

第 3 項 一側上頸神経節剔出群

i) 一般所見

剔出側に明確な縮獞之時には眼結膜の軽度の充血を見 た.この群では 2 カ月の長期に亘つて飼育したものもあ つたが剔出側の縮畗は生体固定時まで続いた，食欲不 振，下㾥等の一般症状は大したこともなく，死亡する例 は1例もなからた。

ii）病理組織学的所見

1) 剔出後 2 日目固定群

剔出側は 1 . 2 回転に，顕著な場合は第 3 回転にる二 ルチ器の膨張像が見られた (No.40, No. 59) が, No. 58 では正常であつた，即ち有毛細胞及び支持緗胞の胞体林 明るく，核む透明度を增している，第 2 回転に最も著明 でこの部分ではラ氏膜が軽度弧状を 呈する例むあつた (No. 40). 前群と此較してその膨化の程度には特に差林 無からた。.内外リンぺ腔は概して清澄であるが; No. 59 では第 1 回転終部から第 2 回転初部侄る内リン人腔内

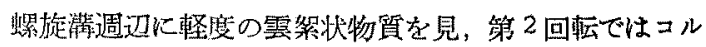
千膜が柱細胞の上端に㾤着されている。その他の部分に は特に变化を認めなかつた。

反対側でる No. 58 , No. 59 では剔出側と同じょうな コルチ器の膨張を $1 ・ 2$ 回転汇認め, 前著では第 1 回転 内リンペ空に少量の雲絮状物買が見られた．その他血管 条, 螺旋踢带, 螺旋神経節等恃雨側とも正常であつた。

口）剔出後 2 週間目定群

コルチ器は 1 -2 回転, 殊に第 2 回枟で枟度䏽化し胞 体は淡染する。.この膨張像は比校的軽度であるが両側に 
見られ左右同程度であつた。内外リンぺ腔は清澄で， 血管条，螺旋软带，螺旋神絟節等は全く正常であつた (No. 61).

\section{八) 剔出後 2 力月目固定群}

コル千器の各細胞は左右とも膨化気味の場合が多く正 常の事もあつたが，萎縮を示寸場合は然かつた，血管

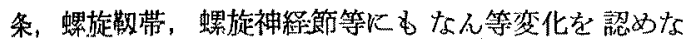
い.この群に極めて特微的である事は剔出側の内外りン へ膑に限つて見られた，大量の雲絮状物質の出現である (No. 9, No. 10, No.11). この雲絮状物質はへマトキシ 》ンに淡染する均質な物質で，全外リンぺ腔に亘り外側 3 分の 2 ないし3 分の1を埋めている。外リンべ腔上り は少いが内リンペ腔にも外側寄りに比較的大量存在す る. 反対側の内外リンベ腔は全く清澄であるが，1・2 回転の鼓室偝内隅に極くわずかの雲絮状物質を見る例も あつた (No. 10).

\section{），墨汁染色群}

No. 42 の剔出側 1 .2回転の血管状は墨汁で清染され

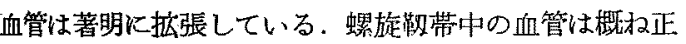
常である。対側では正常標本に比しやや漕染し，血管 の軽度の㹡張を思わしめるが，剔出側よりは明らかにと の程度は弱い. No. 56, No. 57 でも剔出側で血管集の血 管拨張を見るが，反対側での血管隍影は正常の走行を去示 した.

\section{第4 項 小 括}

頸動哌洞神経を両側剔出すると全例に捻いて血生の上 昇を認めた，上梨の割合怙々によつて差はあるが，5 例を平均すると約 $30 \mathrm{mmHg}$ に及んた゚。病理組織学的に は血管条血管に著明な収縮を見るのみで，コルチ器及び 内外リンべ腔には著变を見なかつた。

交感神経上頸神経節剔出群の特徽西る所見はコルチ器 を棈成する絧胞の膨化，内外リンべ腔に括ける雲絮状物 質の出現及び血管条の血管执張がある．時期的に見れば 細胞の膨化は剔出 2 日目群炕著明で，2週間後及び 2 力 ，月後の標本では膨化気味であるが正常であつた，雲䋈状 物質の出現はこれとは逆に，2 日目群及び 2 週間目碓に はわずかで， 2 カ月飼育したものでは顕著であつた。

又一側剔出群の左右差については結果があちまちで特 に差はなく，時期的に朓めても一関した㖽向は見られな かつた.

要するに循環調節障害動物の変化は血管条の血管の収 縮又は脑張，コルチ器細胞の膨化、リンパ膑の零絮状物 賀の出現であり，蝸牛諸組織には破壊的变化の全然見ら
れないこ上を碓かめ得たのである。

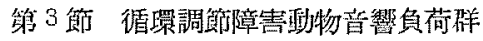

洞神絿剔出 家鬼は 2 回日の手術を終立て 1 週間後よ り，上頸神経節剔出家乘小剔出後 2 日目上り音篦負荷を 開始した。負荷音響は W.N. で第 1 節で確かめた如く， 音響のみでは螖牛に障害をきたす事のない110フォン・ 1 時間/日・連続 10 日の条件である。全身所見は循環調 節障害動物音響非負荷群つ其々の場合と同じであるが， 音響負荷が進むにつれて食欲不振，下浰が続き死亡与る 場合がかなりあつた。

第 1 項 頸動脹洞神絽剔出啡

コルチ器は全例に机いて強い音響障害刀像を見る。即

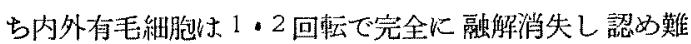
い、第 2 回忶では有毛細胞のみならずダイテル氏細胞及

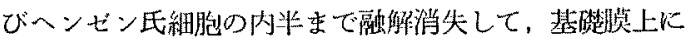
大きな空隚を作りコルチ器は先の輪漷をとどるるに過ぎ ない(No. 15, No. 19, No. 37, No. 39). 第 1 回転で消 失するに至るのは有毛細胞とダイテルス氏緗胞で，他の 支持細胞はよくその形態を保つか (No.37)，溷濁腫張 し核の濃縮を見るにとどまる(No.19，No.39).No.15 で支支持細胞が著明溷濁蒌縮し，各緗胞の竟界は全く 不明膫で核の位管異常も見られた。第了回枟ではコルチ 器各細胞土軽度溷罚するにとどをり，有毛細胞子消失士 るには至らなかつた，No. 36 では特に障㸷が藷しく，

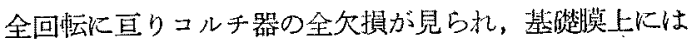
何西見られなからた。

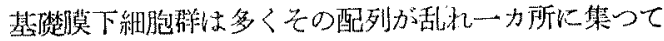
集塊を作る傾向が見られるが，No.36では㱠しど消失 しェオジンに好染した基礎莫が赤い均賀な带状物として 見られるに過ぎない、コルチ傥はとの形熊を保つ場合が

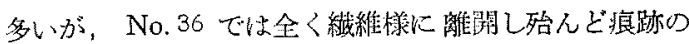
み認めるばかりの部分もあった：ラ氏膜は正常である。 血管条では血管が猳杖収縮の傾向を見せ，血管条全体が 浮腫状となり融解しかけている像も見られた，螺旋勒带 には著变を見なからた。

リンパ空は一般に清明でするが，No. 19 の左侧 1.2

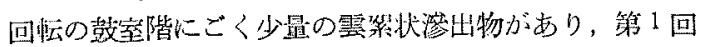
枟では内リンへ腔にも見られた。NNo. 36 では第2 2 回枟 内リンハ腔内下隅に，薄桃色のあたか子扁平上皮癌の真 珠核の如きものがあり，恐らくコルチ器細胞の融解迶物 ではないかと思われる。

螺旋神絟節細胞には著多を認めなかつた。 


\section{第 2 項 両侧上頸神経節剔出群}

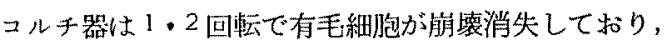
No. 46 ではダイテルス氏細胞及びヘンゼン氏細胞す融 解し，その部分が空洞を形成している。ダイテルス氏細 胞が牫存する場合でも障害は支持細胞に及び，胞体は溷 濁し核も浱縮して, 各縕胞の境界は不鮮明となり全体と して板状に变形している(No.47, No. 48). 第 3 回転で る各緗胞に整度の溷濞が見られ境界も不明膫となるが， 有毛細胞が消失するには至らなかつた。

基礎膜下細胞群出少し細胞が減少し配列も乱れ，集団 化の傾向が見られた。特にNo.46 に著明であつた。 ルチ膜は膨化する場合もあったが概して変化なく，ラ氏

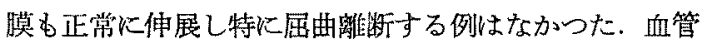
条は正常ないし軽度の血管拡張を示し，No. 46 では第 2 回転終部で全体が浮腫状となり部分的に融解し小さな空 胞を形成した，螦旋歇带には特に变化を認めなからた。

内外リンペ腔は一般に清澄であるが，内リンぺ腔に需 絮状滲出物の浮游する例 (No. 46) もあり，第 2 回転で は核と思加れる物貿を含む出所不明の細胞が点在してお。 り, 恐らくコルチ器細胞の崩㯰したものが游離したもの と思われる。

螺旋神経節細胞に著变を認めなかつた。

第 3 項 一側上頸神経節剔出群

本群は剔出側と区対側では障害の程度に 差が見られ た. 先ず剔出側では全例において1・2 回転で有毛絸胞 の消失が見られるばかりでなく，各支持細胞も洞䚑菱縮 し細胞の境界は不鮮明となる（No. 28，No. 52, No. 53， No. 54 , No. 55). 殊にNo. 54 では第 2 回転初部でュルチ

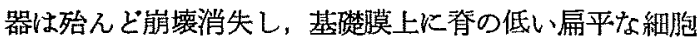
塊としてその痕跡を認めるばかりである，第3回転は 各細胞の軽度溷㯰にとどまるのみである，反対側では No. 28 だが比較的正常に近い形態を保つが，他の例 では剔出側と同様有毛細胞の消失支持細胞の溷罚筑繀が 見られた，左右を此較すると No. 52,No. 54 はほぼ同 程度の障霄であり，No. 53，No. 55 の障害は剔出側より も軽かつた。，又No.29では人間の聴器の標本では度々 見られるのであるが、コルチ器が㮃維し扁平となりラ氏 膜がンルナ器及び血管条と瘉着する所謂 Neuroepitheldegeneration によく似た像が得られた。

基礎膜下細胞群は多く配列異常をきたし細胞も減少 する場合が多からた。コルチ膜は瀻維化の見られる例 (No. 54) もあつたが㯕して正常である. ラ氏膜も大体 正常に伸展するが，No. 55 で活離断を認ふる回転むす
つた，血管条は正常ないし軽度の血管惤張が見られた。

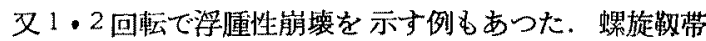
に著変はない

内外リンぺ空は一般に清澄であるが，No. 55 の第 1 回転鼓空階に小出血がみられた。蝶旋神释簛には著变が なかつた。

第 4 項 小 括

特徽的所見はいつれれ群でも全例に音幚障害の像とし て知られる破壊的变化の得られた事である。最む著明な 変化を見たのはコルチ器で内外有毛細胞の消失及び支持 細胞の消失ないし溷潈である。この变化は 1.2 回轱が 主で，コルチ器の全欠損を招いた一例を除いて第 3 回転 では溷濁にとどまり有毛細胞も消失するには至らなかつ た，基磷膜下細胞群も細胞の減少，集団化，配列異常が 見られた，その他コルチ膜の䋐維状離開，ラ氏膜の離 溯，血管条の浮蕾性崩噫等が部分的に見られた。

洞神経剔出群，両側上頸神経節剔出群，一側上頸神経 節剔出群のそれそれれの破壊的变化の間には云々する程の 差は見られなかつた。唯，一側上頸神綎節剔出群の非剔 出側心剔出側に較ぺて明らかに軽い障害を示したものが 約半数あつたが，それとても音響障害の像は存在した.

\section{III 電商生理学的研究}

1930 年 Wever と Bray 19) が音響刺㦸によつて内耳 から音波に一致した電気的变動の 誘導される 掫を発見 し，これを聴神経の A.P. (Action potential) と考支た が，その後 Adrain が蝸牛内からら最も顕著に誘導される 事を強調しこの現象を C.M. (Cochlear microphonics) と名づけたこの C.M. は有毛細胞と関俰が深く， Howe 及び Guild 11)（193〜33, 1935）はラ氏膜や基礎 膜は健全でコルチ器の烦している Albino cat では C.M. が証明されない栾を示した。 Streptomycin を大 量に投与して 有毛細胞を障慧すると C.M. は検出され なくなる38).このよらにC.M. は德党刺㦸に対する有毛 緗胞の交流反応であり，聴喾電気生理の上から見れば㯖 力構成上の第一の必要条件で, これが聴神経織維を刺战 乙 Impnlse を発生せしめる，従つて C.M. は聴賞自体 ではないが，末梢感覚器としての内耳の機能を代表する ものであると云う事ができる，前編では長期間䮴音刺战

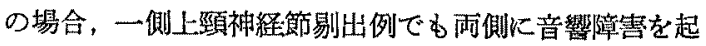
すことを知つたので，短期間騒音刺战における聴器の態 度を知るために C.M. を指摽とする電気生理学的実験を 行つた。 


\section{第 1 章 実呀動物並びに実験方法}

第 1 節 弮験 動物

病理組織学的军験に供したと同じ $2.0 \sim 2.5 \mathrm{~kg}$ の健康

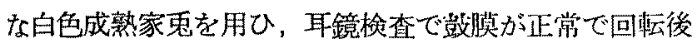
眼振に異常のないのを確かるて使用した。

第 2 節 实歌装置

実験室には阪大耳鼻科学教空の防音室を使用し，音傮 湘定，写真撮影等の操作は副室で行つた．舀験淩置の Blockdiagram は第 4 図に示寸加くである。

第 4 図 Blockdiagram

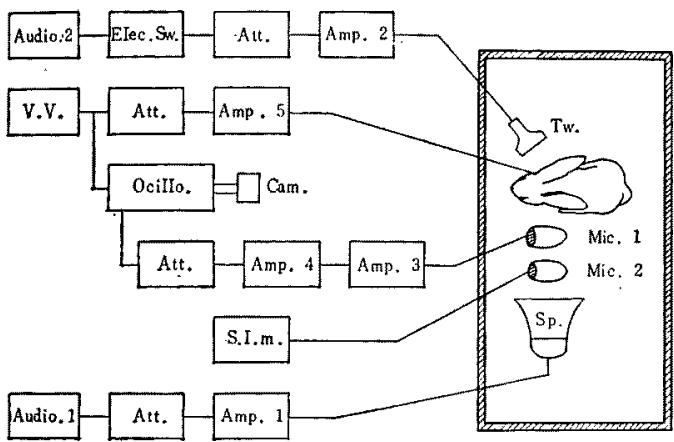

即ち音源系装置としては

Audio. 1: ヨシノツクス 51-D オージオメーター Amp. 1: 山水 Q-3535 電厈增幅器

Sp. 1: 30W レフレックスホーンスピーカー この利列から W.N. 在発振せしめた。

Audio. 2：永島 51-A オージオメーター

Elec. Sw.：電子スイッチ SB-01 型 (リオン製)

Amp. 2: 山水 PM-100 電压增幅器

Tw. : ソウイーター（パイオニヤ製 $\mathrm{pt}-5$ )

この采列から $2 \mathrm{KC}$ の Tone pipを発振せしめた。

反応澌定系装琶としては

Mic 1：ダイナミックマイクロフォン（産研製 MS-3）

S.l.m.：指示䮎音計（リオン製 N 1103)

Mic. 2: コンデンサーマイクロフオン

Amp. 3：電王增巾器 (Brüel \& K Kaer 製)

Amp. 4： VC-6 附属 AVH 型前琶堌巾器

Ocillo. : 二光軸ブラウン管オシロスコープ（日本光電 製 VC-6)

Amp. 5：VC-6 附属 AVB 型前顛增巾器

Cam. : キアノンー7

斜線は音響的並びに電気的に遮蔽された防音空を示 \$.
第 3 節 C.M. 誘学法

家鬼を腹位に固定し雨耳翼を前方に㲤引し，制毛局所 麻酥後 Lateral approachにて中耳骨胞を露出した，骨 胞には手術用のパーで正円空の見える位珇に3〜4mm の小孔をあけた，電極にはェナメル塗有して絶緑した直 径 $0.2 \mathrm{~mm}$ の銅線を用い, 先端 $2 \sim 3 \mathrm{~mm}$ の絶縁をはが

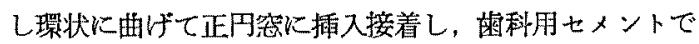
骨胞に固定した。他極は頸筋内に装着し不関電極として 接地せしめた。

C.M. 誘導法には種々の力法があるが，正円空誘導法 を採用した理由は，一つは操作が簡単であり他は無麻酔 で操作する事ができるからである，又後述の如く然麻

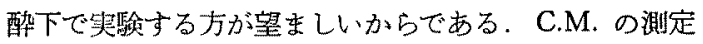
に際して留意せねばならぬのは音響以外の因子による C.M. の動㩊である。その原因としては本誘導法では主 に正円空膜の破損及び硬脸膜の露出であるが，個体に上 つてはかかる明らかな原因がなくても C.M. の低下を

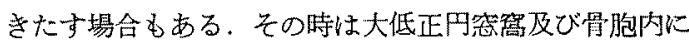
は多量の液体の溷留を見る事から，恐らく骨壁に開けた

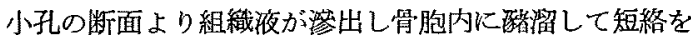
生じたためと思われる。この上うな原因による C.M. の低下を除外するために予倩具験として C.M. 在誘導 し放監した所，不自然な C.M. の低下が起る場合は誘 尊後 30 分以内に現われた，最初の30 分に変動をきたさ なければ，以後少くとも2 時間は変動が㴆からた。従つ て C.M. を誘導して30 分間放䈯しその变動のないのを 確かめてから実験に䔟つた。

第 4 節 負荷条件及び観察方法

交感神経上頸神経節の剔出は病理組織学的実駼と同し 万法で行い，剔出 3 时間後に音響負荷を開始した，音薌 負荷は 110 フオンの W.N. を自由音場で 30 分間㯖取せ しめ，2kc の純音を測定崤としてその後の C.M. の回 復を钼察した，測定音白体による疲労を避けるために起 ら上り時間 $25 \mathrm{msec}$., 持続時閜 $30 \mathrm{msec}$. の Tone pip として与克，強さは特性曲線の直線部分に和いて $70 \mathrm{db}$ とした.この Tone pipはカメラのシヤツターと連慗 させ，シャッタ一を押すと一個の pip が出るよらにし， 負荷終了時より 20 分閒撮影した，测定点としては負荷 終了直後より 1 分間は 5 10 秒每次の 2 分間心 30 秒每， 10分迄山1分每，その後は2 分每である。第5図はTone pip 及びその C.M. を示す。詶测には写真を引引き伸ば し各 C.M. の大きさを計り，負荷前の C.M. の大きさ 它 $100 \%$ として目荷後の C.M. の減少を百分率で表わ 
第5図 Tone pip とその C.M. (上: C.M., 下: Tone pip)

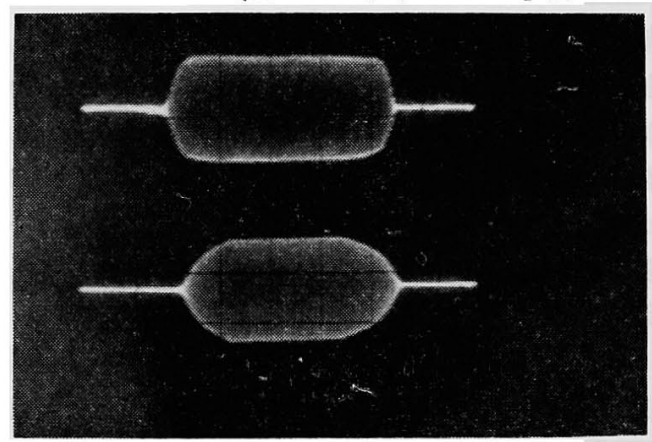

し回復曲線を作成した.

第 5 節 無麻酔新導について

自律神経に対する作用因子は手術操作に伴う圧迫や牽 引，実験室の温度や湿度，さらには麻酔薬の影響等があ る. 手術は上頸神䋊節以外への外力の及ぶのをできるだ け避忖, 室温も $24^{\circ} \mathrm{C}$ に調節し, 麻酔に関しても皮膚切 開に伴ら極く少量の局所麻酔 $(0.5 \%$ プロカイン) 以外 は一切支用せず，以後の操作を無麻酹下で实験した。無 麻酔下で寻騷するに際して塸念されるのは，音に警いて 暴れたり動いたりする事であるが，実駼中ノン゙キ空から 家鬼の状態を钼察すると音響負荷開始洔には暴れるが， その後㥧れるのか平静で殊に負荷終了後写真撮影の時に 動く事はなかつた，時には固定している首輪をはずした り，体動が続きノイズの混入を見た例もあつたが，実験 成績からは除外した。

\section{第 2 章 実験 成 績}

第 1 節 正 常 啡

負荷前の C.M. の值を $100 \%$ とし, 負荷後の各反応値 の減少を百分率で表わすと第 2 表の如くなり，これに基 いて 回復曲線を作成すると第6 図の如くなる。即ち 30 分真荷後の C.M. の低下け最小 $21 \%$, 最大 $42 \%$ で 5 例 の平均は $31 \%$ であつた. 曲線は負荷終了後溸くは急速 な回復を示し, 各々最大低下の $50 \%$ を回復するのに要 する時間は最初の 1 分問であつた。1分を境に漸時緩 やかに直線的に回復し，10 分後では殆んど回復寸るか (No. 110, No.111, No.113)，6〜8\%の減少を示打の で (No. 115, No. 117), 15 分後には全例が 4\% 以内の娍 少を残すのみで殆んど貞坷前の状態に戻つた．各例によ つて最大低下の值が異なるため，各々別々に20 分後に 最大低下の何\%を回復したかを亦す最終回復率け 5 例の 平均が 90\%であつた。
第 2 表 正常群に拈ける C.M. の減少百分率

\begin{tabular}{|c|c|c|c|c|c|}
\hline 封間 & No.110 & No.111 & No.113 & No.115 & No.117 \\
\hline 後 & $40 \%$ & $26 \%$ & $26 \%$ & $42 \%$ & $21 \%$ \\
\hline $5^{\prime \prime}$ & 29 & 19 & 18 & 30 & 17 \\
\hline $10^{\prime \prime}$ & 29 & 19 & 18 & 25 & 14 \\
\hline $20^{\prime \prime}$ & 24 & 17 & 18 & 25 & 14 \\
\hline $30^{\prime \prime}$ & 19 & 17 & 18 & 22 & 14 \\
\hline $40^{\prime \prime}$ & 19 & 14 & 18 & 22 & 14 \\
\hline $50^{\prime \prime}$ & 19 & 14 & 18 & 19 & 14 \\
\hline $1^{\prime}$ & 19 & 14 & 16 & 19 & 12 \\
\hline $1^{\prime} 30^{\prime \prime}$ & 17 & 12 & 13 & 19 & 12 \\
\hline $2^{\prime}$ & 14 & 12 & 10 & 19 & 12 \\
\hline $2^{\prime} 30^{\prime \prime}$ & 12 & 12 & 10 & 1.9 & 12 \\
\hline $3^{i}$ & 12 & 9 & 8 & 17 & 10 \\
\hline $4^{\prime}$ & 12 & 9 & 8 & 14 & 8 \\
\hline $5^{\prime}$ & 5 & 9 & 8 & 14 & 8 \\
\hline $7^{\prime}$ & 5 & 2 & 8 & 8 & 8 \\
\hline $10^{\prime}$ & 3 & 2 & 3 & 8 & 6 \\
\hline $14^{\prime}$ & 0 & 2 & 3 & 4 & 4 \\
\hline $20^{\prime}$ & 0 & 2 & 3 & 4 & 4 \\
\hline 最䅂回復率 & $100 \%$ & $92 \%$ & $88 \%$ & $90 \%$ & $81 \%$ \\
\hline 均 & & & $90 \%$ & & \\
\hline
\end{tabular}

第 6 図正常群の回復曲線

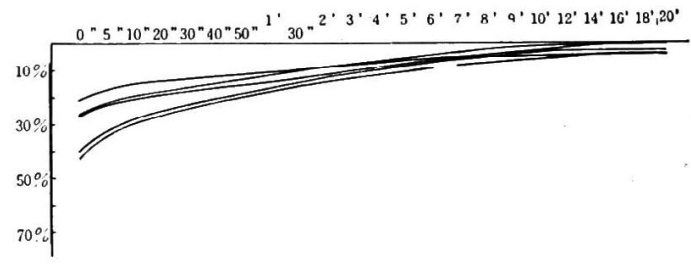

第 2 節 雨側上頸神経節剔出群

本群の減少百分率は第 3 表に, 回復曲線は第 7 図に示 す如くである。即ち C.M. の最大低下は最小 $32 \%$ から 最大 $84 \%$ に及び，平均 $57 \%$ と非常に大きな低下を示し た. No. 125 を除いては最初緩やかな回復を示すが，以 後は殆んど回復が起らず回復曲線は水平型となる. 即ち No. 124, No. 128 では 20 秒後から, No. 125, No. 126 では 5 分後頃から横ばいの状態で, 完全回復を示寸もの は一例もなかつた，最終回復率の平均も $24 \%$ と非常に 悪からた。 
第 3 表 两侧上頸神経節剔出群の C.M. 減少百分率

\begin{tabular}{|c|c|c|c|c|}
\hline 家香番号 & No. 124 & No. 125 & No. 126 & No. 128 \\
\hline \multirow[t]{7}{*}{ 且 } & $32 \%$ & $58 \%$ & $84 \%$ & $53 \%$ \\
\hline & 27 & 48 & 78 & 50 \\
\hline & 25 & 47 & 78 & 50 \\
\hline & 25 & 45 & 75 & 47 \\
\hline & 25 & 45 & 75 & 47 \\
\hline & 25 & 43 & 72 & 47 \\
\hline & 25 & 43 & 68 & 47 \\
\hline $1^{\prime}$ & 25 & 42 & 68 & 47 \\
\hline$l^{\prime} 30^{\prime \prime}$ & 25 & 42 & 65 & 47 \\
\hline $2^{\prime}$ & 25 & 42 & 68 & 47 \\
\hline $2^{\prime} 30 \prime \prime$ & 25 & 42 & 68 & 47 \\
\hline $3^{\prime}$ & 25 & 42 & 65 & 47 \\
\hline $4^{\prime}$ & 25 & 42 & 65 & 47 \\
\hline $5^{\prime}$ & 25 & 42 & 65 & 47 \\
\hline $7^{\prime}$ & 25 & 38 & 62 & 47 \\
\hline $10^{\prime}$ & 25 & 38 & 62 & 47 \\
\hline $14^{\prime}$ & 25 & 38 & 62 & 47 \\
\hline $20^{\prime}$ & 25 & 38 & 62 & 47 \\
\hline 最終回復綔 & $22 \%$ & $34 \%$ & $27 \%$ & $11 \%$ \\
\hline 平均 & & & & \\
\hline
\end{tabular}

第7图画㑚上頸神経節剔出群の回復曲線

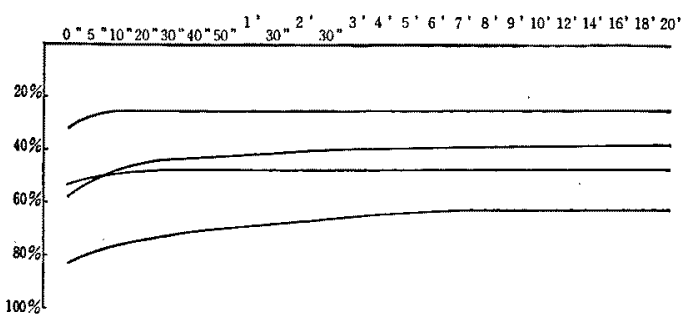

第 3 節 一側上頸神経節剔出群

C.M. の娍少百分率は剔出側が第 4 表に非剔出側は第 5 表に示卞如くで，回復曲線は第8图の如くである。こ の群の特徽は左右で差の認められる事である。即ら非剔 出側では C.M. の最大低下は17〜30\%で 4 例の平均は 19.4\%であり，時間の経過と共に順調に回復し No. 132 を除いて 20 分後には砝んど元の 状態に戻つた。つまり 正常群に近似した曲線となる。一例（No.132）のみは 1 分 30 秒後加 Б殆儿ど回復讨寸゙，最終的にも $15 \%$ の C.M. 減少を残し，従つて最終回復率の平均は $76 \%$ で 正常群の 90\%とは少し差が見られた。
第 4 表一側上顡剂経節剔出群の剔出侧の C.M. 減少百分率

\begin{tabular}{|c|c|c|c|c|}
\hline 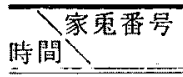 & No. 132 & No. 133 & No. 135 & No. 136 \\
\hline \multirow[t]{7}{*}{ 直 } & $34 \%$ & $32 \%$ & $25 \%$ & $38 \%$ \\
\hline & 32 & 22 & 23 & 30 \\
\hline & 30 & 17 & 23 & 27 \\
\hline & 30 & 15 & 20 & 27 \\
\hline & 30 & 15 & 20 & 27 \\
\hline & 27 & 12 & 22 & 24 \\
\hline & 27 & 12 & 20 & 24 \\
\hline $1^{\prime}$ & 27 & 12 & 20 & 24 \\
\hline$l^{\prime} 30^{\prime \prime}$ & 27 & 10 & 22 & 24 \\
\hline $2^{\prime}$ & 27 & 7 & 22 & 22 \\
\hline $2^{\prime} 30^{\prime \prime}$ & 27 & 7 & 22 & 19 \\
\hline $3^{\prime}$ & 27 & 7 & 22 & 19 \\
\hline $4^{\prime}$ & 27 & 7 & 22 & 19 \\
\hline $5^{\prime}$ & 27 & 7 & 22 & 19 \\
\hline $7^{\prime}$ & 27 & 5 & 20 & 19 \\
\hline $10^{\prime}$ & 27 & 2 & 20 & 19 \\
\hline $14^{\prime}$ & 27 & 2 & 20 & 19 \\
\hline $20 \prime$ & 27 & 2 & 20 & 19 \\
\hline 最終回復窈 & $21 \%$ & $94 \%$ & $20 \%$ & $50 \%$ \\
\hline 平均 & & & & \\
\hline
\end{tabular}

第 5 表 一側上項神経節剔出群の非剔出側の C.M. 減少百分事

\begin{tabular}{|c|c|c|c|c|}
\hline 家哥番号 & No. 132 & No. 133 & No. 135 & No. 136 \\
\hline \multirow[t]{7}{*}{ 直 } & $30 \%$ & $23 \%$ & $17 \%$ & $27 \%$ \\
\hline & 24 & 15 & 11 & 19 \\
\hline & 22 & 15 & 11 & 16 \\
\hline & 22 & 13 & 11 & 13 \\
\hline & 22 & 13 & 11 & 13 \\
\hline & 20 & 13 & 11 & 13 \\
\hline & 20 & 13 & 8 & 13 \\
\hline $1^{\prime}$ & 20 & 10 & 8 & 13 \\
\hline $1^{\prime} 30^{\prime \prime}$ & 17 & 10 & 8 & 10 \\
\hline $2^{\prime}$ & 17 & 8 & 8 & 10 \\
\hline $2^{\prime} 30^{\prime \prime}$ & 17 & 8 & 8 & 10 \\
\hline $3^{\prime}$ & 17 & 8 & 8 & 10 \\
\hline $4^{\prime}$ & 17 & 8 & 8 & 8 \\
\hline $5^{\prime}$ & 17 & 8 & 8 & 5 \\
\hline $7^{\prime}$ & 17 & 6 & 5 & 5 \\
\hline $10^{\prime}$ & 17 & 6 & 5 & 5 \\
\hline $14{ }^{\prime}$ & 17 & 6 & 3 & 5 \\
\hline $20^{\prime}$ & 15 & 6 & 0 & 5 \\
\hline 最終回復和 & $50 \%$ & $74 \%$ & $100 \%$ & $81 \%$ \\
\hline 平均 & & & & \\
\hline
\end{tabular}




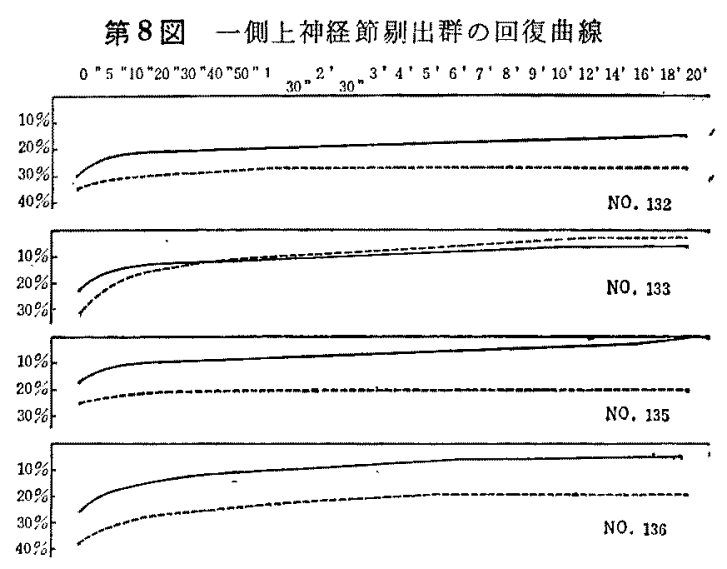

(-...-别出㑡，一棐剔出侧)

これに対して剔出側では最大低下が 25〜38\%で，そ の值は各個体に和いて区刘例上り大きかつた。その後の

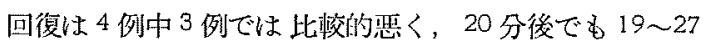

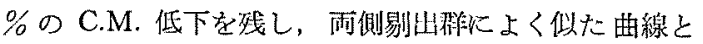
なる。一例 (No.133) の多性回復が薪明で 20 分後には 完全に元に厌つた，最終回復琼も46\%で非剔出側と其 に正常群と耐側剔出群の中間的存在を示した。

第 4 節 小 括

正常群の C.M. 区応値は傎荷終了直後 20 40\%の低 下を示し，1 分問で大休その中间まで回復し 15 分後に は殆えど元に唇つた。

雨側剔出群の最大低下は30〜80\% と広筑囲比亘りば らつきが大きい しかし最大低下の值にかかわらず，い ずれも回復は極めて恶くて回復曲線は平坦となつた。

一側剔出群乡土两者の中間的状態を示した. 即ち剔出側 は両側剔出群に似て回復が㤠く水平型となるが，両者の 相違は最大低下の值にあり，一側剔出群剔出側は 25〜 40\%とばらつきが少く，正常群と同じ筂因にある。非 剔出側は回復も順調で正常群に似て和り，両者の相違は 殆んど元まで 民户るに正常群が 15 分であつたのに対し て20分を要した点である.

\section{IV 総括並びに考按}

1886 年 St. v. Stein 㧊よび Havermann が海犋聴器 の音響による退行变性を認めたのを籍矢として，㗹器の 音嫏障害に関する組織学的研究山今世紀初頭 Wittmaack 20) 始め Sicbeumann, 吉井 21)，Marx 16) 等によつ て始められ次第に活発となり Hössli ${ }^{12)}$, 松井, Popoff 17) 等を翡出し，生体固定法の創案と相侯つて幾多の整

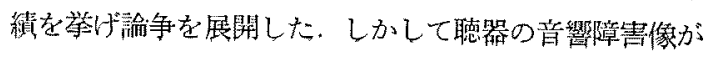

外有毛細胞の装縮变性に初まり，刺㦸時日の経過と共に 漸次内有毛細胞，支持細胞に及び，最終的にはコルチ器 の消失を見るに至る一連の变化である事は今日すで周 知の事䒠となつている。

この種の研究は最初音知覚現象の解明を目標とした が，高エネルギーの発見に伴い特殊な環境にしか見られ

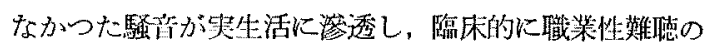
問題が注目され，この方面の研究情々の治療中䂆放策 に向けられるようになつた， $\mathrm{C}^{5}-\mathrm{dip}$ を初発とする職業 性蜼聴を含め種々の感音系蜼聴は，いまだ治療面で十分 な效果は期待し膜く，重点は専ら予防対策に向けられ， 種々な対策が䛾じられているが職業性難聴患者は增加の 傾向をたぞる璝状である。これは騷音の抑制及び防音設 備には限度がある可，又はたと充相当効果が期待できて も資金面漠倠のある中小企栄の多い日本の社会临勢を反 映しているに他ならない，それ故に䂆方対策を進める一 方河田 ${ }^{29)}$ 30）等の主張する如く，職業選択の面から音響 外傷受傷性の解明が肝要で，この問題が耳目を集めるの も当然の成り行きといえよう，音響詨する低抗性の強 弱认個体炕より差があり，同し職業同じ環境で働く作業 員の間でも，無症状で経過する者から種々の程度の難㯖 者に遭偶するのは日常絽驗している所である。個人によ るかかる差異は従来個体差，内的因子あるいは先天的弱 質なる言葉で呼ばれ一見当然の如く考えられていたが， 最近その言葉の包含する内容について検討されて来てい る. かかる内的因子の究明に関して Antoli 1) (1959), Gottesberge 19) (1959) 等は個体差の規定は困難である と匙を投げているが，一方伎䏚 37) (1957) 沖中毒量以 下の聴器毒投与により音響受傷性が元進する赫を彗験的 に結論し，田中 ${ }^{39)}$ (1952) 《耳管閉塞症の存在する場 合音響に上る内耳病変発生に促進的に働く之云い, 藤野 47)（1950），土肥 40)（1953）等は慢性穿孔性中耳炎を有 する個体は逆に音響刺㦸に対して防止的に働くと述べて いる. 河田 ${ }^{30)}$, 安逢 ${ }^{23)}$ (1957)，山川 50) (1958) 等忙自 律神経の態度と関連せしめ, その失調状態士音響受傷性 をえ進すると述べ，更に山川は一定の精神祭張は受傷 性を低下すると云つている，松原 ${ }^{49)}$ (1957)，菊池 ${ }^{39}$ (1957) 等は内因としてレ線照射，肝腎障害を挙げ，そ の肝筲障篦㥀接・問接的に自律神経を介して内耳血管 系何らかの影響を及ぼしているからであると述べてい る、本論交はかかる観点にたら，内耳が高度に分化した 神絟緑胞及び多数の毛細血管を持つ複雑な器管であり， しかもその血流山終末動挀に由来寸る所から，循環調節 
の障害を手術的に起し，その音響受算性がいかに变化す るか炕ついて研究したものである。

实験動物には古くから海㩧が多用されているが，洞神

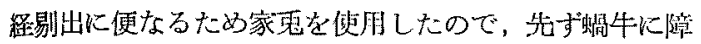
㕩を起与刺战量の決定を行つた。その結果 W.N. 120 フォン・1時間/日・連続 10 日の刺㦸では強力な音響障

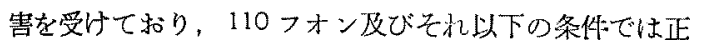
常であつた.つまり1日1時間の W.N.を連続10日間 負荷するならぱ，110フオン以下の音量では何らの障慧

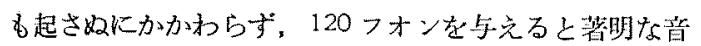
響によるコルチ器破壊像を見る，つまりこの条件では音 響障害を蒙るか否かの境界は 110 フォンと 120 フォンの 闌にあると云光る. Gerhardt u. Wagner 9) (1962) が

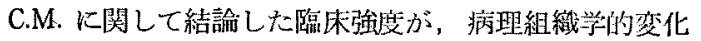
についてもほ涪同様に云光るようである，それ以上の強 大音掣では新井 ${ }^{24)}$ (1962) が130フォンのW.N. を与 え1日 4 時間 1 回の負荷で, コルチ器細胞は破壞轱移寸 ると云う報告をしている．以上の成續上り頸湎脈洞神経 または交感神程上頸神経節を剔出した家鬼に，䛻界強度 以下である110フォンの W.N. を連続10間日（1 時間 旧）真荷与る州比した。

莖動脈洞神絽化ついては最初 Czermak (1866) が胸 鎖乳突笳上縁を王迫し脈博数の減少するのを発見したの

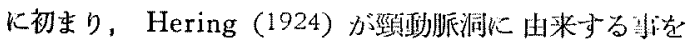
つきとめ，ここを围繶する神絽を Sinusnerven と称党 た、この神経は Sinus caroticus 及び Glomus caroticum 上り出る知覚神絓で主に吉咽神程に，一部心迷走 神絽，舌下神絟及び 交感神経上頸神経節に入り，项㲜 眨洞から来る衙整を伝え血王の調節に関与している。 徉つて該神経の切除に上り持続性高血生を招米与る柿 をMies ${ }^{14)}$ (1920) によつて称充られて以来, Hering (1929) 他多くの学者により確諗さ机ている。本其制で は 5 例の洞神経剔出家电で剔出於後の血比を测定した が，全例に血圧の上昇を認わ平均上昇值は $29 \mathrm{mmHg}$ で あり，顕著な場合は $44 \mathrm{mmHg}$ に及儿でいる。藤崎 46) （1952）も同様な力浩で $30 \sim 40 \mathrm{mmHg}$ の上早を見，長 期間持続したと報告している。川野ふ11)(1940)は長い、 むのは 1 年以上に亘つて飼青䧋祭し，普通は 20〜40 $\mathrm{mmHg}$ の上貿をきたすが，甚しい場合は 80〜100 $\mathrm{mm}$ $\mathrm{Hg}$ にも及ぶと述べている。これ程顥著な例は絟唋しな からたが，恐らく飼育期間の長短及び耳翼中心動脈測定 法を用いているので，測定法の相違にもよるかも知れな い，血王上昇の生理を考えるに，钼政脈洞は血生の变
化，共際には上昇を感受しこれを洞神絟に上り中枢に伝

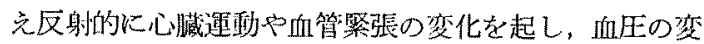
化を調節しこれを正常に復帰せしめるものである，従つ て該神縚の切断山この反射症なくし，中枢からの抑制が

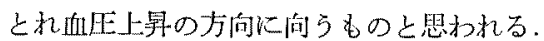

洞神経剔出家象では病理組織学的に内耳特に変化小 なく、コルチ器初め緺牛の各部分は正常の形態を保持す る.川野 い) は有毛細胞の崩垻する例はなかつたがコル 于器の笑縮を多く認めて㧍り，これは大動脈硬変や左室 肥大等の変化をきたす迄 100 300日の長期に亘つて飼 台したためと思われる。この頸動眽洞を剔出し血生上昇 のある家鬼に騒音を鱼荷すると，内耳病理組織学的所 見は洞神経剔出のみの家東に此し非嫦に罢つてくる. 即 ちこの家乘群は強い音響障害を蒙るのである。しかも負

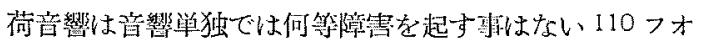
ン・1 持問/日・連続10日の刺㦸に和いてである。即ち 代表呐所見は内外有毛細胞初めコルチ器支持細胞の崩壤

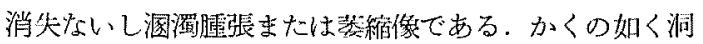

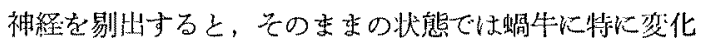
を見ないが，音響と云う外力が作用すると变化を起す量

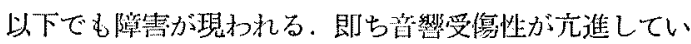

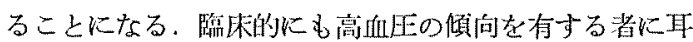

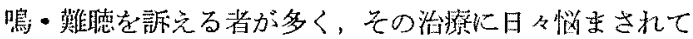

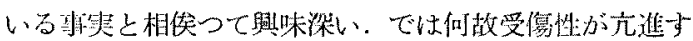

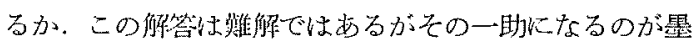
汁染色の所見である。即ち血管条の血管㥩著明に収繀し ている、これは蝸牛への流血最の娍少，つ类り資血の状 態でひいては局所的な酸素欠乏を意味し，強度音響之云

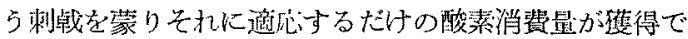
きず，細胞代謝の円滑文欠く絬果でいないかと推祭され る. 即ち洞神程剔出の直接则影楿ではなく，そのために

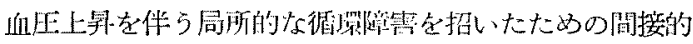
影艟に上るものと思われる。

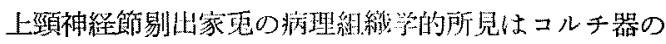
膨化，内外リンバ控の雲絮状淩出物の出現，血管条の血 管拨張で代表される、コルチ器の膨張は剔出後の期間が 新しい場合は诸明であつたが，2週間以上経過したもの では怪㥏の膨化を示少易合も正常の場合も認められた。 上頸神絟節剔出家象の病理組織学的所見については，秋 山 22)（1955）は 1 週間以内の 場合は膨張を示し， 1 3 週間では倠縮が見られたと云つているが，時日の経過に 伴ら膨張一秝縮と云5関係は成立しなからた。北条 ${ }^{48)}$ （1962）は２７ カ月に亘つて飼育し膨張・正常・薮維の 
三者が見られたと報告しているが，本駚験では最長つカ 月のためか萎絤を認めたものは哭かつた。一側剔出家鬼 に和ける非剔出側にも同様の变化を認める例もあつた が，結果はまりまらでその程度についても左右で㕕々す る程の差はなかつた。秋山，北条等は剔出側に著明で非 剔出側では槙にそれより微弱な変化があつたと述べてい、 るが，この上らに明確な程度の差は見出世なからた。 ま た北条は尖端回転程著明であつたと述べているが，著者 の場合 1 -2 回転に著明で第 3 回転では不明瞪であり相 反する成結となつて表われた，内外リンハ膑の墨絮状態 滲出物については明らかに時閏的な関係が見出され，初 期群（2日後，2週間後）ては極くわずかの量で両側に 見られたが，2力月群では全例とb大量に海溜し内外り ンバ腔の外側 3 分の1ないし3分の 2 埋める程であつ た.しか子剔出側にのみ存在し反刘側のリンハ腔は全く 清登であつた. Démétriades ${ }^{5}$ の云う如くリンパ球の 遊出は見られなからた。かかる滲出物や細胞成分につき Guild 惯く少量ならば正常状態でも存在すると述べ ている。しかし2カ月群の如く大量でしかも剔出側に限 つて存在した㢦は，上頸神絽斯剔出と何等かの関係を有 するように思われるが，その成因をさぐる成続は持ち合

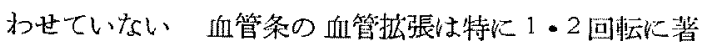
明であり，尖端回轱ほど著明であつたと云う北条 ${ }^{48)}$ と は逝の結果であつた。雨則剔出群では殊に箸明であり， 一側剔出群では明らかに剔出側に著明で妨つた。

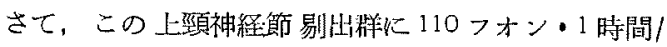
日・連続 10 日の W.N. 次負荷与る上, 洞神経剔出の場

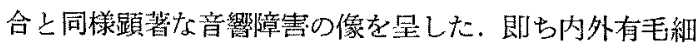
胞及び支持細胞群の崩壊消失ないし溷濁濃維である。こ

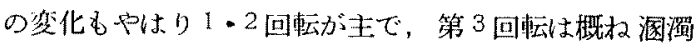
にとどまり有毛細胞の消失を見るには至らなかつた。こ の刺㦸㽬はそれ自体では障害を起すに足ら奴量ですりな がら音留障害を起した事になる。元来自律神絹系なるも のは一旦緩急ある時，その事態に促応し得るためのるの

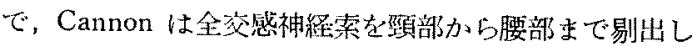
ても全然刺戟の加わら状態を保ら得るならば，何年閒 子健康を維持して生存せしめる事が可能であると述べて いる．換言すれい゙自律神絽の Unbalance がある時，普 段は常の状態上变りないが，一旦何等かの剌㦸を受けた 場合初めてその失調状態を露呈する隶になる。本牙験に 則して云らならば正常妆態ては110フォンの騒音を10 日間被つてもそれに順応できるが，上项神経節を剔出し て交感神経失調状態にある洔はうまく順応できす障害を
蒙る事意味する、しか子與味深いのは長期間刺皒を受 ける時, 一侧剔出例でも雨側火障管を見る事で, 不可逆 性变化を起し得ない程度の短期刺战に拈ける態度を知る ために，C.M. を指摽とする疲労实験を行つた。

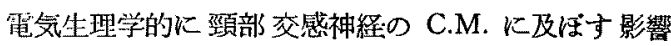
については多くの研究がなされているが，その切断の影 瑟については渡边 ${ }^{52)}$ (1961) が上頸神経節を剔出寸る と C.M. 㵊初 $5 \mathrm{db}$ 以内の上昇を認めるが 30 分後よ り漸次低下すると報告している．Beickert 2)(1956) は

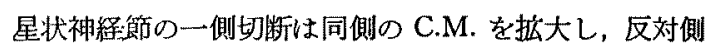
の C.M. 学縮少すると云う左右逆方向えの変動を見たと 報告している。棸との刺㦸の影響についても Seymour

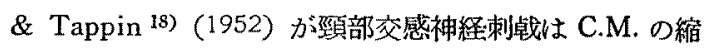
少をきたすと云らに対して，Krejci \& Bornschein ${ }^{15}$ (1954) は頸部交感神経刺战でも星状神経節の刺战です C.M. に及ばす影響林なかつたと結論している。かくの 加く頸部交感神縚の C.M. に及ぼす影㗽について諸家 の成績は必ずしも一致を見ていず，研究方法自体の複雑 さを物語つている，その意味で强大な W.N. を負荷し て維少した C.M. の回復を見る万法を々つて観察した。

可験は 110 フォンの W.N. を30 分負荷し, 終了後よ り $2 \mathrm{KC}$ の Tone pip に対する C.M. によつて回復課 程を追求した，負荷終了直後の C.M. の最大低下は正 常群で 20〜 40\%で各々によつて差があり，殊に両側剔 出群ではばらつきが大きく所謂個体差儿よるむのと思わ れるので, 各々 20 分間で C.M. の最大低下の何\%を回 復したか走示す回復率炕けを閥題にすると，正常群では $81 \sim 100 \%$ で多くは $90 \%$ 前後を示すに刘して，雨側剔 出群では11〜34\%を回復するのみで 極めて恶い，とこ ろが，一側剔出群の非剔出側は 1 例の及 $50 \%$ しか回復 しながたが他は 74〜100\%の回復率で正常群に近く、 剔出䁚は94\%を回復した 1 例を除いて $20 〜 50 \%$ と雨側 剔出群火類似する。この間の事情は一例性障害のある時 非剔出側な刺战に順底しうるが剔出側は順応できない事 を意味し，上然神释節は聴器に対して一側性支配をして いるか主に同側に影璬を与えており，同程度の雨側性支 配を営んでいない静を物語るものである。

项部效惑神経の内耳に対する影響を推論するに，一つ は交感神释の直接作用であり他は交感神経を介しての内 耳血行の開題である、前者については上頸神経節からの 繊維が内頸動脈周辺の神経業を経て頭蓋内に進入し，腷 底動脈から分岐する内耳動脈に沿つて内耳に到達すると 考学られる。この遠心路を想定する事により剔出側では 
疲労を受け反対側では殆んど正常である疲学実跧の結果 と一致する．従つて同側晌う遠心路は十分推察できる のであるが，少くともこの直接作用たけでは長期間の刺 载を受けた時，一側剔出例でも両側障害をきたす事䒠を 説明する事はできず，又違つた二次的な作用機序が働、

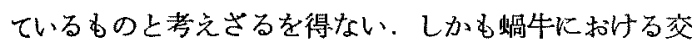
感神経綗維は有毛細胞初めコルチ器に分布すると云う報 告はなく，Ernyei 7) (1936) 等により骨軸の血管壁汇諗 められているに過ぎない，又，今日自律神経と血管系が 密接な関係を有する事は疑いを入れ双事実であり，且つ

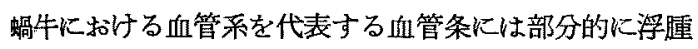
性崩壊像を認め，墨洲染色では著明な血管抖張を示す 等, 音響受賃性の六進には内耳血管系が重要な役割を演 している事を類推せしめる。 その血管㹡張が paralytische Lähmung の状態即ちウッ血状態にある結果, 拡張 するにあかかわらす酸素欠乏になつているのではないか と考学られる。それ血管条の血管壁には涓平筋の存在 が認めら机ない所から passive な搪張を考えるべきで あるら. 要するに上頸神経節剔出後内耳血行の障害を招 き，血管系の特臸として時日の経過と其に両側にまたが $り$ ，蜡牛全体が音響に対して所謂 Locus minoris resistentiae の状態にある，換言す机ば音響刺戥を受け易い 一種の準備状態となつている結果受傷性が立進したもの と思われる。

\section{$\mathbf{V}$ 結 語}

白色成熟家鬼の音響受傷性につき病理組織学的並びに 電気生理学的に追求し次の如き結果を得た.

1) 1 日 1 時間の W.N. を連続 10 日間負荷する時, 110 フォンでは全く正常であるが120フォンでは高度の 音響障害を起した。

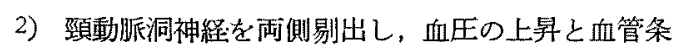
の血管収縮を見た。

3）交感神絟上頸神経節を剔出し，コルチ器細胞の膨 化, 内外リンハ腔の雲絮状出物の出現，血管条の血管 拆張をさたした。

4) 頸動脈洞神絽又は交感神程:上頸神経節を剔出儿, これに音響単独では变化を起さない110フォン・1時間 1日・連続 10 日の W.N. を負荷し，高度の音響障害を 起した.この変化はコルチ器では $1 ・ 2$ 回転に著明であ り，一側剔出の場合も両睢に障害を見た．血管条にも浮 腫性崩垻をきたした。

5）音響負荷後の C.M. の回復は両側上頚神経節を 剔出すると極めて悪く，一側剔出の場合剔出側は雨側
剔出群比似，非剔出側は正常群比近似した。

6) 以上に上り项動脈洞神経又は交感神経上頸神経節 を剔出すると音響受傷性の㠵進する事を確認した，その 機転については内耳血管系の障害による二次的なもので ある事を推論した。

\section{參考文献}

1) Antoli, F.: Das akustische Trauma, Zbl. f. H.N.O. Heilk., 66; 183, $1960 . \quad$ 2) Beickert, P., Gisselsson, L. u. Löfström: Der Einfluss des sympathischen Nervensystem auf das Innerohr, Arch. Ohren-usw. Heilk. u. Z. Hals-usw. Heilk., 168; 495, 1956. 3) Békésy, G. v.: DC Potentials and Energy Balance of the Cochlear Partition, J. A.S. A., 23; 576, $1951 . \quad$ 4) Davis, H.: A Mechano-electrical Theory of Cochlear Aciton, Ann. Otol. Rhinol. \& Laryngol, 67; 789, 1958. 5) Démétriades, Th. D.: Experimentell-pathologische Untersuchungen über die vasomotorischen Störungen des Gehörorgans, Msch. f. Ohrenheilk. u. Laryngorhinol., 59 ; 1074, 1925. 6) Derbyshire, A.J. \& Davis, H.,: The Action Potentials of the Auditory Nerve, Amer. J. Physiol. 113; 476, 1935. 7) Ernyei, I.: Die Elemente der Nerven und Ganglien des inneren Ohres, Arch. f. Ohren-usw, Heilk., 141; 343, 1936. 8) Fowler, E.P.: Sudden Deafness, Ann. Otol. Rhinol. \& Laryngol., 59; 980, 1950. 9) Gerhadt, H.J. u, Wagner, H.: Die Wirkung dosierter Geräuschbelastung auf die Mikrophon Potentiale der Meerschweinchenschnecke, Arch. Ohren-usw. Heilk. a. Z. Hals-usw.

Heilk., 179; 458, $1962 . \quad$ 10) Gottesberge, M. z.: Das akustische Trauma, Zbl. f. H.N.O. Heilk, 66; 186, 1960. 11) Howe, H.A. \&. Guild, S.R.: Absence of the Organ of Corti and its Possible Relation to Electric Auditory Nerve Responses, Anat. Rec., 55; 20, 1933. 12) Hössli, H.: Experimentell erzeugte professionelle Schwerhörigkeit, Z. f. Ohren-usw. Heilk., 69; 225, 1913.

Kobrak, H.G.: Die angioneurotische Oktavuskrise, Beitr. z. Anat. etc. d. Ohres, d. Nases u. d. Halses, $18 ; 305,1922$. 14) Koch, E. u. Mies, H.: Ein neues Verfahren, den Blutdruck an Tieren ohne Gefässeröffnung zu messhn, Z. f. d. ges. exper. 
Med., 62; 551, 1928, 15) Krejci, F. \& Bornschein, H.: The Cochlear Microphonic Potentials During Sympathetic Stimulation, Acta Otolaryngol., 44; 154, 1954. 16) $\operatorname{Mar} x$, H.: Untersuchungen über experimentelle Schädigungen des Gehörorgans, $Z$. f. Ohren-usw. Heilk., 59 ; 333, 1909.

17) Popoff, N.F.: Zur Frage über die experimentell durch Schallreizung hervorgerufenen Veränderungen in der Schnecke, Msch. f. Ohennheilk. u. Laryngorhinol., 57; 704, 1923. 18) Seymour, J.C. \& Tappin, J.W: The Effect of Sympathetic Stimulation upon the Cochlear Microphonic Potentials, Acta Oto-laryngol., 42; 167, 1952. 19) Weber, E.G. \& Bray, C.W.: Action Currents in the Auditory Nerve in Response to Acoustical Stimulation, Proc. Nat. Acad. Sci., 16; 344, 1930.20$)$ Wittmaack, K.: ¿̈ber Schädigung des Gehörs durch Schalleinwirkung, Z. f. Ohren-usw. Heilk., 54; 37 , 1907. 21) Yoshii, U.: Experimentelle Untersuchungen über die Schädigung des Gehörgans durch Schalleinwirkung, Z. f. Ohren-usw. Heilk., 58; 201, 1909. 22) 秋山登: 頸部交感种経と聪器との関俰,

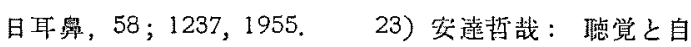
律神経の態度に関する研究，日年奥，59；408，1956.

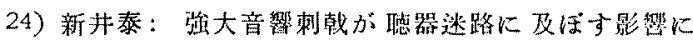
関する寒験的研究，日耳舞，65；1131，1962。25）大

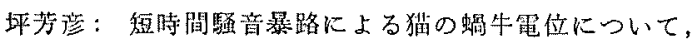

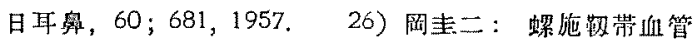

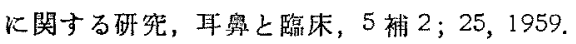

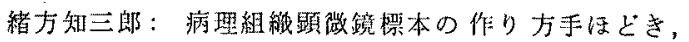

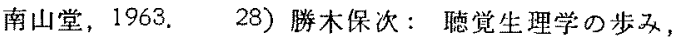
日本音䪪学会誈，10；36，1954，29）河田政一：音

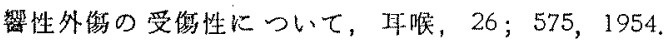

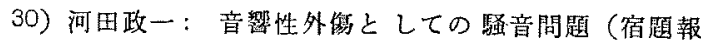
告)，1955. 31）川野多：高血压及び移眽硬化症の聴

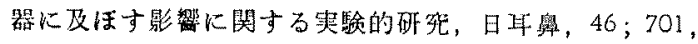

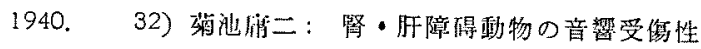
に関与る实験的研究，日耳鼻，60；1602，1957。

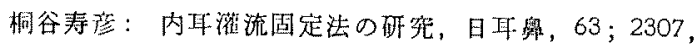

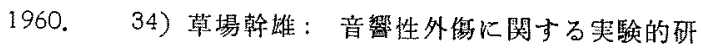
究，耳舆と臨床，9補 2；105, 1963.35) 国付達期： 未発表. 36) 作武安太郎, 他: 生理学詤議, 南山堂,

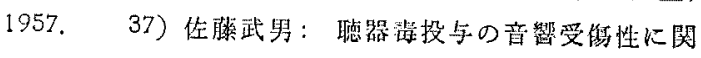

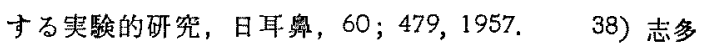

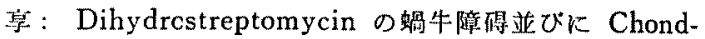
roitin Sulfate の該障碍に対する予防效果に関する実験 的研究，日耳與，60：164,1957。39）田中敬一：音 望刺戙による内耳病変と耳管閉塞症との関保に就いて， 日耳鼻，55；596，1952。40）土肥利：鼓膜の異常

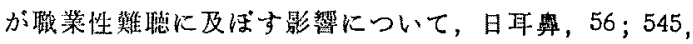
1953. 41) 内藤佔：メ二エール氏病の蹦休之病理 (宿題報告)，1959. 42) 中島礼士：内耳電気生理学

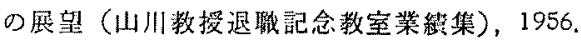

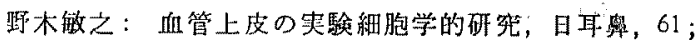
1174, 1958. 44) 長谷川高敏：病気の実体，永井竖 店，1963.45）長谷川高敏：末梢循愣障書上重晢注 射，政床と砳究，37；828，1960.46) 藤嵓茂已：笑

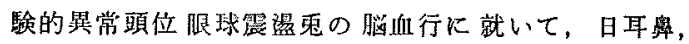

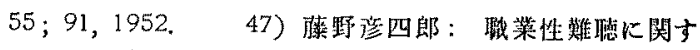

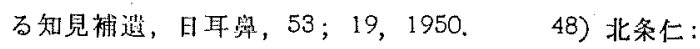

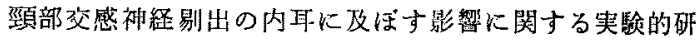
苑，日耳奥，62；57，1962.49）松原莍三：レント ゲン線が音響受賃性に及ばす影㬴に関する实踰的研究， 日耳率，60；1464，1957. 50）山川厚：音製受结性

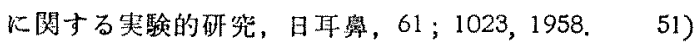

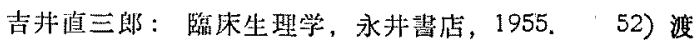

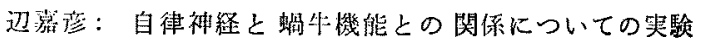
的研究，日耳鼻，64；1325, 1961 .

\section{附図説明}

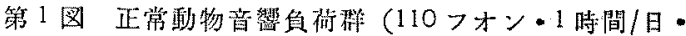
速㑷10日刺㦸)，コルチ器正裳なるを示す(第 2 回耺).

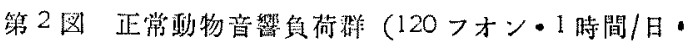
连続 10 日刺戟)、コルチ器の障害を示す(第2 回転).

第3 図頸動脈洞神経剔出洋。コルチ器正常なるを示す (第3 圆枟).

第 4 图頸動脈洞神経剔出群，墨计染也にて血管条血管 の収緶せるを示す(第 2 回枟)。

第 5 図頸動脈洞神経剔出及び掔音負荷群。コルチ器の 障害を示す(第 2 回枟)。

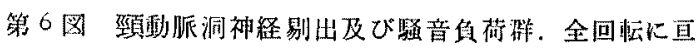
るコルチ器の全久掦を示す。

第 7 図两側上頸神経節剔出群(剔出後 2 日目固定群). 内リンパ腔の雲絮状物留の出現を示す。

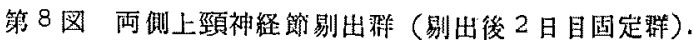


杉山論文附図 (I)

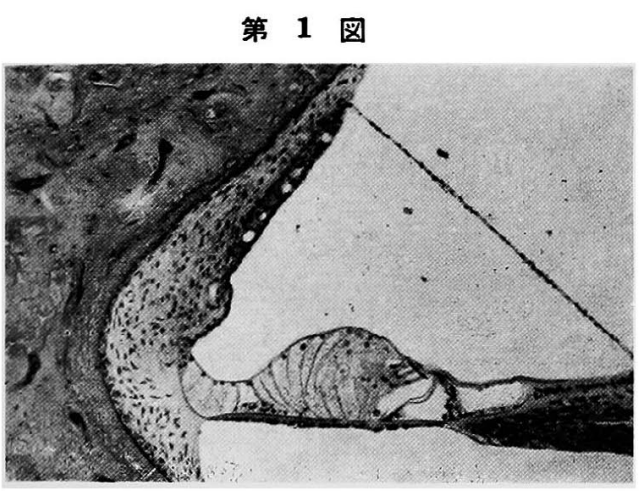

第 2 図

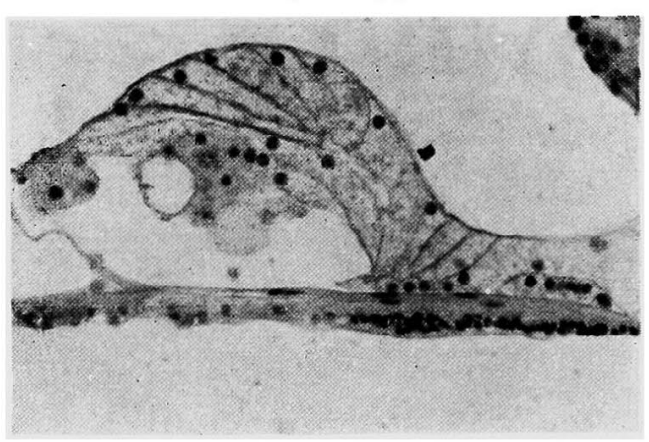

第 3 図
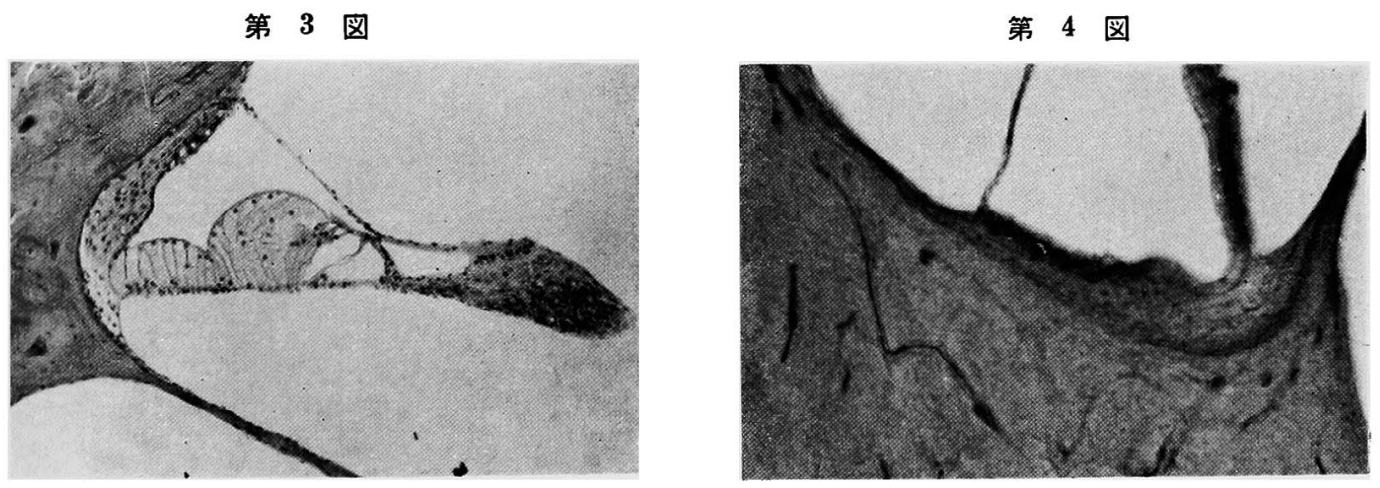

第 5 図
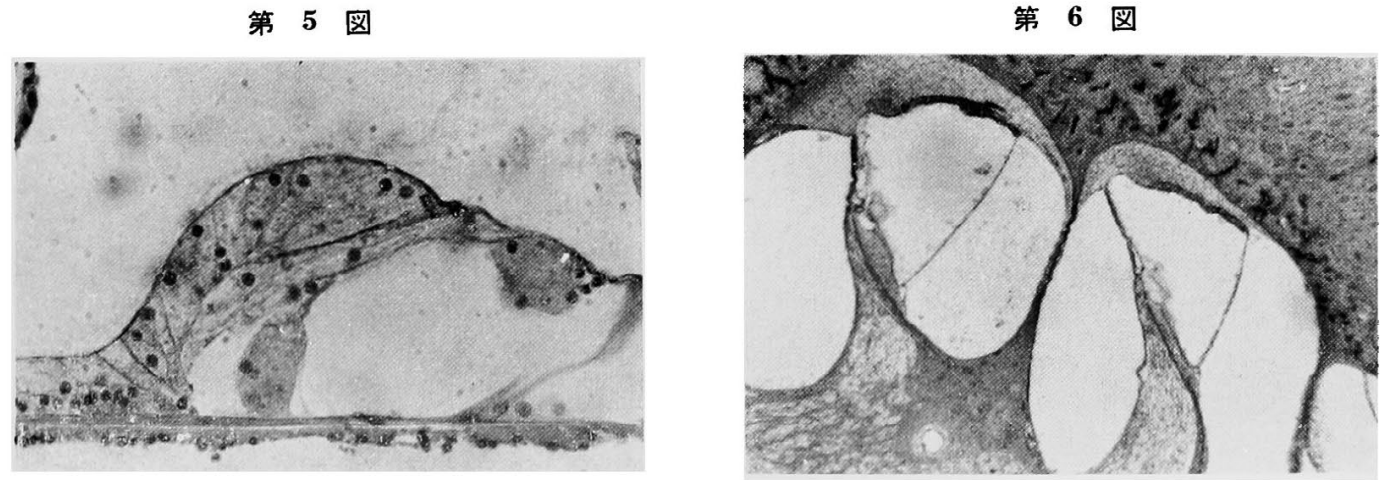
杉山敦交附図（II)

第 7 図

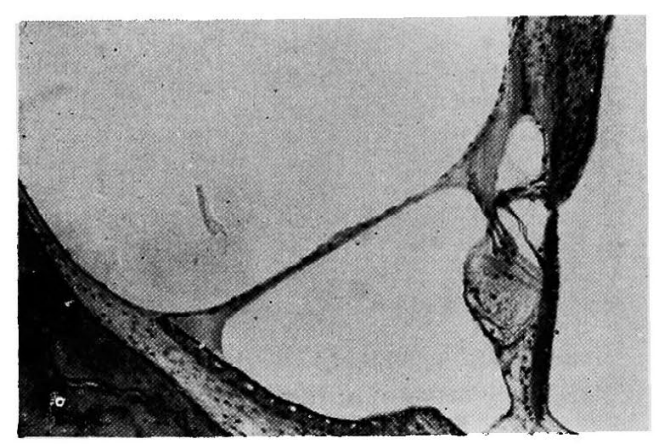

第 9 図

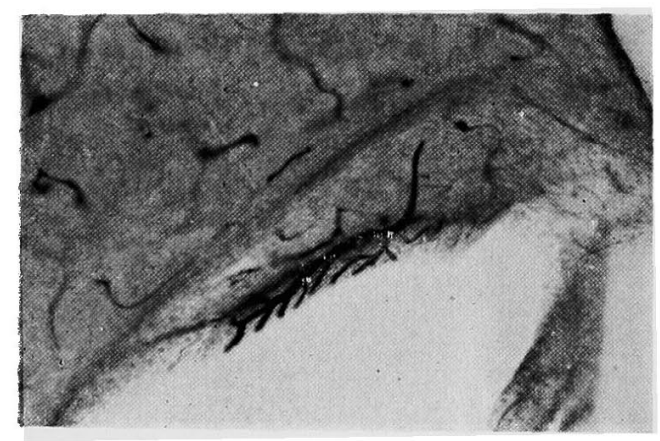

第 11 図

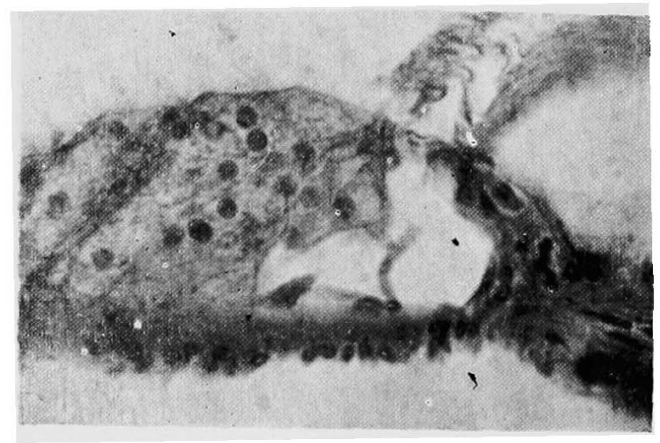

第 8 図

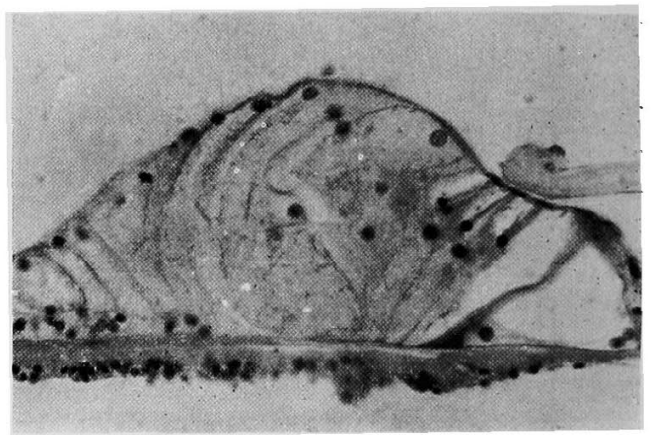

第 10 図

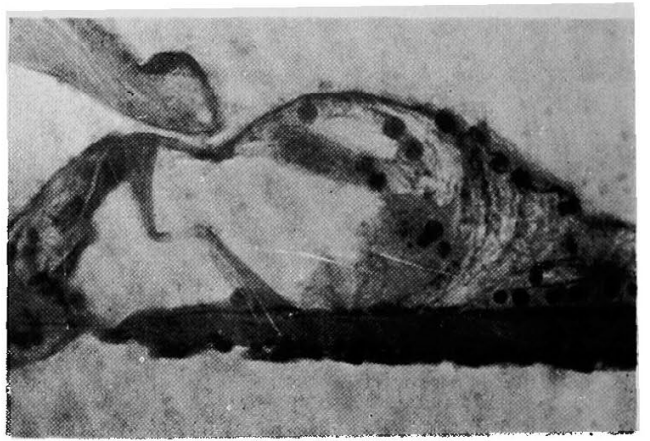

第 12 図

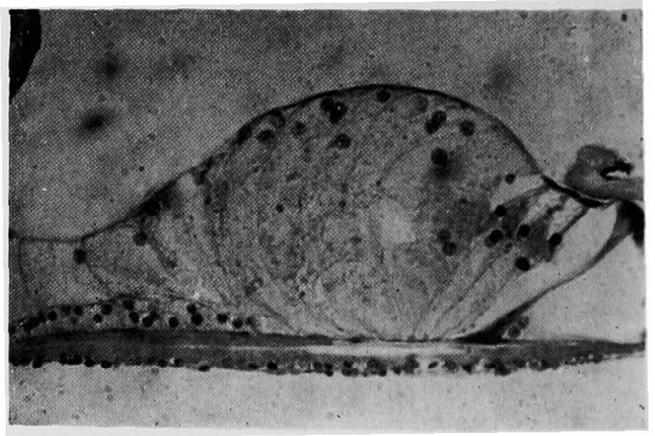


第 13 図

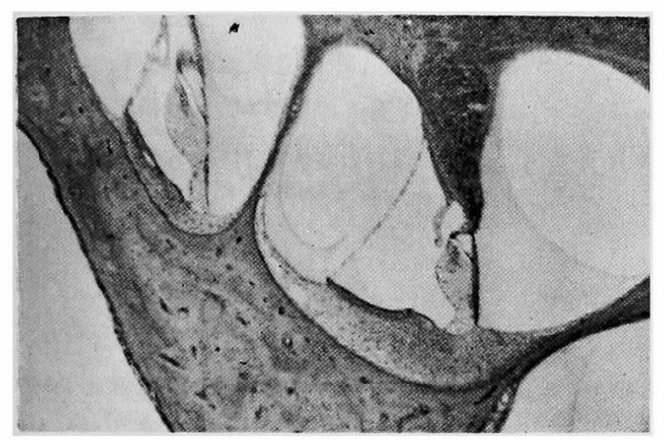

第 15 図

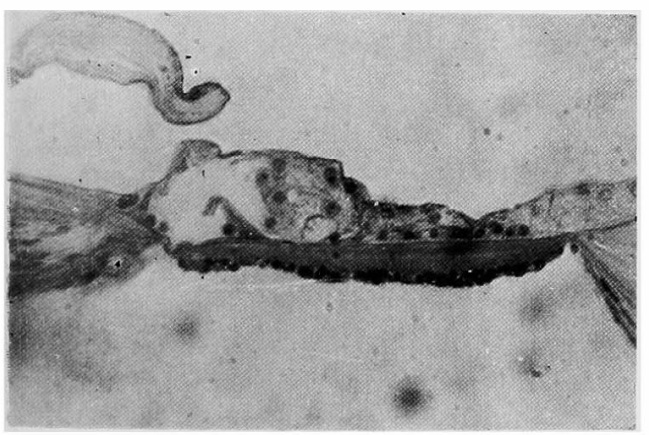

第 17 図

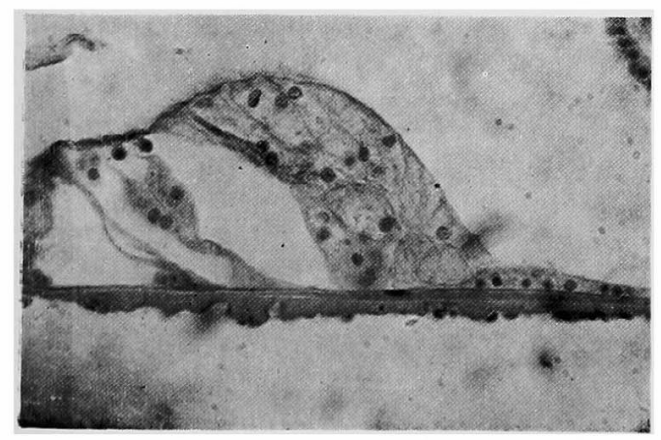

第 14 図

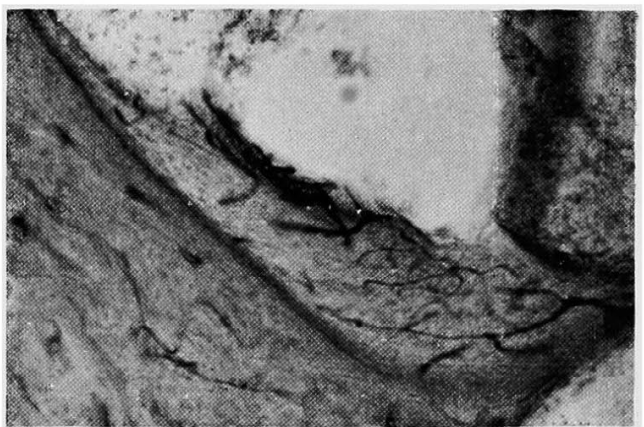

第 16 図

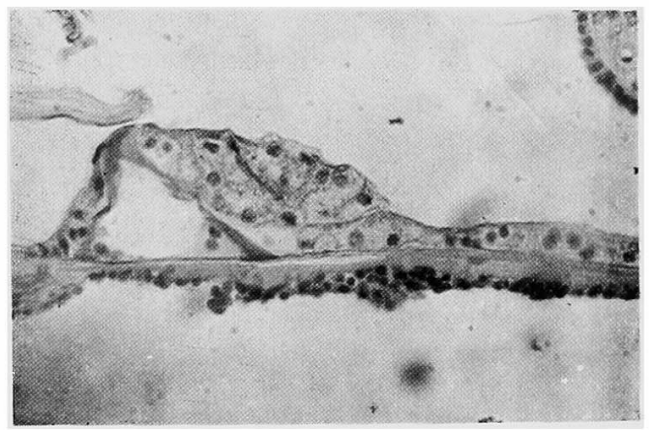

第 18 図

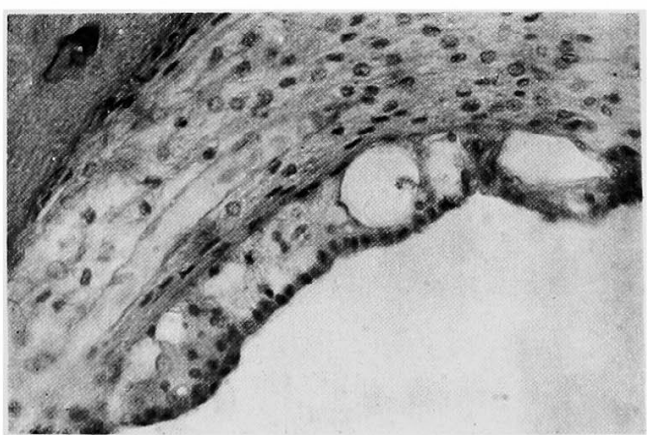


コルキ器の琏化を示す（第 2 回枟）.

第 9 図画侧上项神経節剔出群. 悬汁染色下て血管条血 管の拢張せるを示す(第 2 回転).

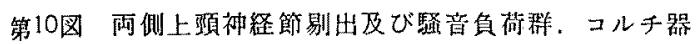
の障害を示す（第1回枟）。

第11图两侧上澌神経節剔出及び騒音真荷群。コルチ器

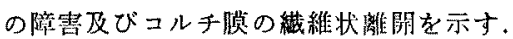

第12园一侧上项神经節剔出啡(剔出後 2 週間目固定礁 非剔出侧)。コルキ器の膨化を示吉(第2 2 回枟).

第13图一侧上頝祖経節剔出据（剔出後 2 力月目国定

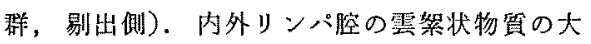
量涰溜を示す。

第14图一侧上项神経節剔出群 (剔出侧). 理汁染色儿 て血管条血管の㧴張せるを示す（第1回枟).

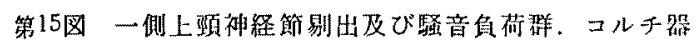
の崩境を示す（第1回転)。(剔出側)

第16图一侧上頸神経節剔出及び䮴者負街群。コルチ器
の崩垻を示す（第 2 回枟），(剔出侧）

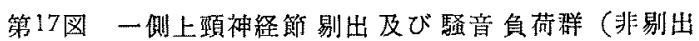
侧)、コルチ器の障害を示す(第2 回呿)。

第18威一僛上顶神経節剔出及び騒音負荷群(剔出侧)。 血管条の浮嗹性崩壊を示す（第1回転）.

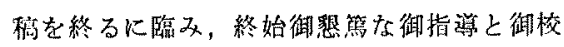

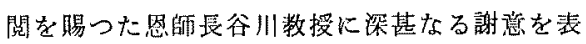
しますまた淔按の御指導，御助言を而いた住 藤，中島，加藤の諸先生に深謝いたします，本 馀交の一部は第 122 回，第 123 国，第 124 回の

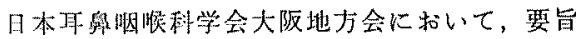
は第9回日本オージオロジー学会総会に批いて 発表した。

（原咥到着=炤和 40.2 .10 日） 